\title{
An Integrated Geophysical Approach to Mapping and Modelling the Karoo Dolerite Intrusions in the South-Eastern Karoo Basin of South Africa
}

\author{
Christopher Baiyegunhi, Oswald Gwavava, Kuiwu Liu and Temitope L. Baiyegunhi \\ Department of Geology, Faculty of Science and Agriculture, University of Fort Hare, \\ Private Bag X1314, Alice 5700, Eastern Cape Province, South Africa
}

\begin{abstract}
The South-Eastern Karoo Basin has several dolerite intrusions that possibly introduced heat into the basin and resulted in the large scale conversion of oil to gas. To date, the geometry of these dolerites and variations in electrical resistivity of the purported shale gas hosting Ecca Group is poorly documented despite over 30 years of research in the area. In this study, we investigate the variations in resistivity of the Ecca Group, estimate the average depths to magnetic signatures and produce gravity models that unravel the basin architecture and how dolerite intrusions are interconnected at depth. The magnetic map shows some ring-like or circular structures which coincide with dolerites that were mapped in the field. Depth slicing revealed that the dolerites are pervasive in the study area, extending up to $5400 \mathrm{~m}$. The Bouguer anomaly map shows gravity values increasing from inland to coastal areas. The gravity models revealed that the dolerites form a network of interconnected sills, dykes and inclined sheets at depth. The subsurface apparent resistivity of the Ecca Group varies between $2 \Omega \mathrm{m}$ and $557000 \Omega \mathrm{m}$. The pseudosections show that the lower Ecca Group rocks are generally characterised by low resistivity compared to the upper Ecca Group rocks.
\end{abstract}

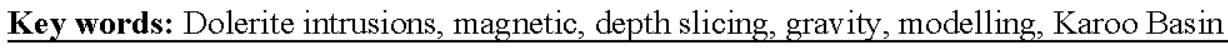

\section{INTRODUCTION}

One of the most noticeable features of the present Karoo landscape is the numerous dolerite sills and ring-complexes. These structures usually show a sub-circular saucer-like shape, the rims of which are mostly seen as topographic highs and form ring-like structures on satellite images (Svensen et al., 2007). The Main Karoo Basin has several dolerite intrusions, thus, providing a special opportunity to study the forms and nature of dolerite intrusions. But on the other hand it has seriously restricted the depth of investigation in many situations (Van Zijl, 2006a). The geographical distribution and geometries these dolerite intrusions in the South-Eastern Karoo Basin are the major tectonic style that possibly controls the geomorphology and drainage system of the basin (Chevallier et al., 2001; Woodford and Chevallier, 2002). In the North, highly resistive rocks of the Kaapvaal Craton underlain the basin and the basin is bounded by the Cape Supergroup in the far South (Van Zijl, 2006b). Its thickness gradually increases towards the south until the Karoo trough is reached in the extreme Southern portion of the basin where thicknesses of the Karoo sequence is about $12 \mathrm{~km}$ (Smith, 1995).
The Karoo Basin's rocks potentially host majority of South Africa's onshore fossil fuel reserve. Petroleum exploration in the Karoo Basin is presently focused on the shale gas, coal-bed methane gas and biogenic gas of the Ecca Group and if viable it will be the main alternate source of energy in South Africa. Previous studies on the group mainly deals with the stratigraphy, sedimentary facies, depositional environment, electrical resistivity and petroleum potential of the basin (Kingsley 1981; Smith, 1995; De Wit and Ransome, 1992, De Wit, 2011; Smith et al., 1993; Johnson et al., 1996, 2006; Catuneanu et al., 1998, 2005; Chevalier et al., 2001; Van Zij1 2006a, b; Geel et al., 2013, 2015; Baiyegunhi and Gwavava, 2016, 2017). Van Zijl (2006a) documented that several deep structural studies in the Karoo Basin were carried out by the Council for Scientific and Industrial Research (CSIR) by means of direct current resistivity sounding and profiling using the Schlumberger array (Kunetz, 1966) between the period of 1966 and 1980. These surveys were said to have been carried out at the request of the Southern Oil Exploration Corporation (SOEKOR) and the Water Research Commission (WRC), respectively. In the Soekor investigation, the deep Electrical Sounding (ES) method was used as a complement to the seismic reflection method, especially in areas where results were seriously

Corresponding Author: Christopher Baiyegunhi, Department of Geology, Faculty of Science and Agriculture, University of Fort Hare,Private Bag X1314, Alice 5700, Eastern Cape Province, South Africa 
affected by the presence of the extensive network of dolerite intrusions. In the WRC studies, ES was used as one of the geophysical methods to study the groundwater potential and deep structure along the Doornberg Fault zone, marking the boundary between the Kaapvaal Craton (situated in the North) and the Namaqua-Natal mobile belt (located in the South) (De beer and Meyer, 1983; Hartnady et al., 1985). The results from both studies show that the very conductive carbonaceous Whitehill Formation of the Ecca Group acts as an electrical basement to deep soundings. Further than its limit in the South and East this basement is highly resistive consisting of igneous and metamorphic rocks of the Kaapvaal Craton and the Namaqua-Natal Metamorphic Belt, respectively. The average sediment resistivity above the whitehill formation in their study area was documented to have increased with depth in the absence of dolerites, perhaps due to weathering effects. As documented by Hunter and Reid (1987), the Carboniferous-Permian Karoo sediments were intruded by the Jurassic Karoo volcanics (183 Ma) as a result of prolonged magmatic activity which covers almost the whole of the Southern African subcontinent during one of the phases in the break-up of the Gondwana. This resulted in one of the four major preserved continental flood basalts in the world (White, 1997). To date, the geometry of these Karoo dolerites are still not well understood and the lateral and vertical variation in electrical resistivity of the Ecca Group is still poorly documented. In this study we mapped and modelled the dolerite intrusions that could have impacted the shale reservoir in order to better understand their geometry within the Main Karoo Basin. The Ecca Group formations outcrop in the study area and are part of the targeted area for petroleum exploration in South Africa. Hence, we investigate and reveal the variation in electrical resistivity of the Ecca Group as well delineate and estimate the average depths of magnetic anomalous bodies within the area.

Geological setting: The Karoo supergroup is the most extensive and thick phanerozoic deposits in Africa and are well-preserved throughout Southern Africa (Fig. 1). The deposition and amassing of the Karoo successions in Southern Africa was in response to the Pangean first-order cycle of supercontinent gathering and subsequent break-up (Catuneanu et al., 2002). Therefore, the Karoo Basin represents episodes of subsidence and sedimentation within the interior of Gondwana (Tankard et al., 2009, 2012) with depocentres changing from a passive continental margin in the early paleozoic to a landlocked foreland basin during the permo-triassic
(Smith et al., 1993). Up to now there is still controversy surrounding the development of the Karoo Basin. Several models have postulated for the development of the basin. Recently, the geological interpretation of the evolution of the Karoo Basin vary from a retro-arc foreland basin that developed due to shallow angle subduction of the palaeo-pacific plate underneath the Gondwana supercontinent (Catuneanu et al., 2002; Catuneanu 2004; Johnson et al., 2006), a transtensional foreland basin formed as a result of subsidence and tilting in a strike-slip regime (Tankard et al., 2009, 2012) to a thin-skinned fold belt that formed as a result of collisional tectonics and distant subduction (Lindeque et al., 2011; Pangaro and Ramos, 2012).

The Main Karoo Basin in South Africa is a large sedimentary depository lying North of a fold belt (Cape Fold Belt). As documented by Milani and de Wit (2008); Linol et al. (2015), the basin thought to have formed within the inland interior of Southwest Gondwana and covers up to $700,000 \mathrm{~km}^{2}$. But it was more broad or wide during the Permian (Aarnes et al., 2010), representing about 117 Ma (300-183 Ma) of sedimentation (Catuneanu et al., 2005). As documented by Johnson et al. (2006), the basin comprises of the Dwyka, Ecca, Beaufort and Stormberg Groups. The whole sequence of deposition is covered by the basalt and pyroclastic deposits of the Drakensberg Group (Fig. 2). The outpourings of the pyroclastic deposits (basaltic lava) reached most part of the Gondwana at about $183 \mathrm{Ma}$, indicating the initiation of Gondwana break-up. The magma moved along fractures and got to the surface. Crystallisation of the magma within these fractures resulted in the dolerite dykes and sills which intrudes the Karoo sedimentary sequence. The presence of numerous dolerites in the basin fed the erupted lava and these sills were linked to the break-up of Gondwana (Johnson et al., 1996).

The palaeoenvironmental settings of the Karoo succession revealed changing climatic conditions as Gondwanaland drifted from high latitudes towards the equator (Johnson et al., 1996; Tankard et al., 2009), varying from glacial and fairly marine (Dwyka Group), through marine and fluvial in the Ecca and Beaufort Groups respectively, then to aeolian in the overlying Stormberg Group (Smith et al., 1993). Several researchers including Kingsley (1981) and Cole (1992) have proposed that most of the Ecca and Beaufort Groups sediments in the Southern part of the Karoo Basin were sourced from the magmatic arc in the Permian time. Nonetheless, during the Triassic, the quickly growing cape fold belt along the Southern margin of the basin contributed meaningfully to the basin fill and perhaps was the main source area for the sediments of the Stormberg Group (Molteno and Elliot 


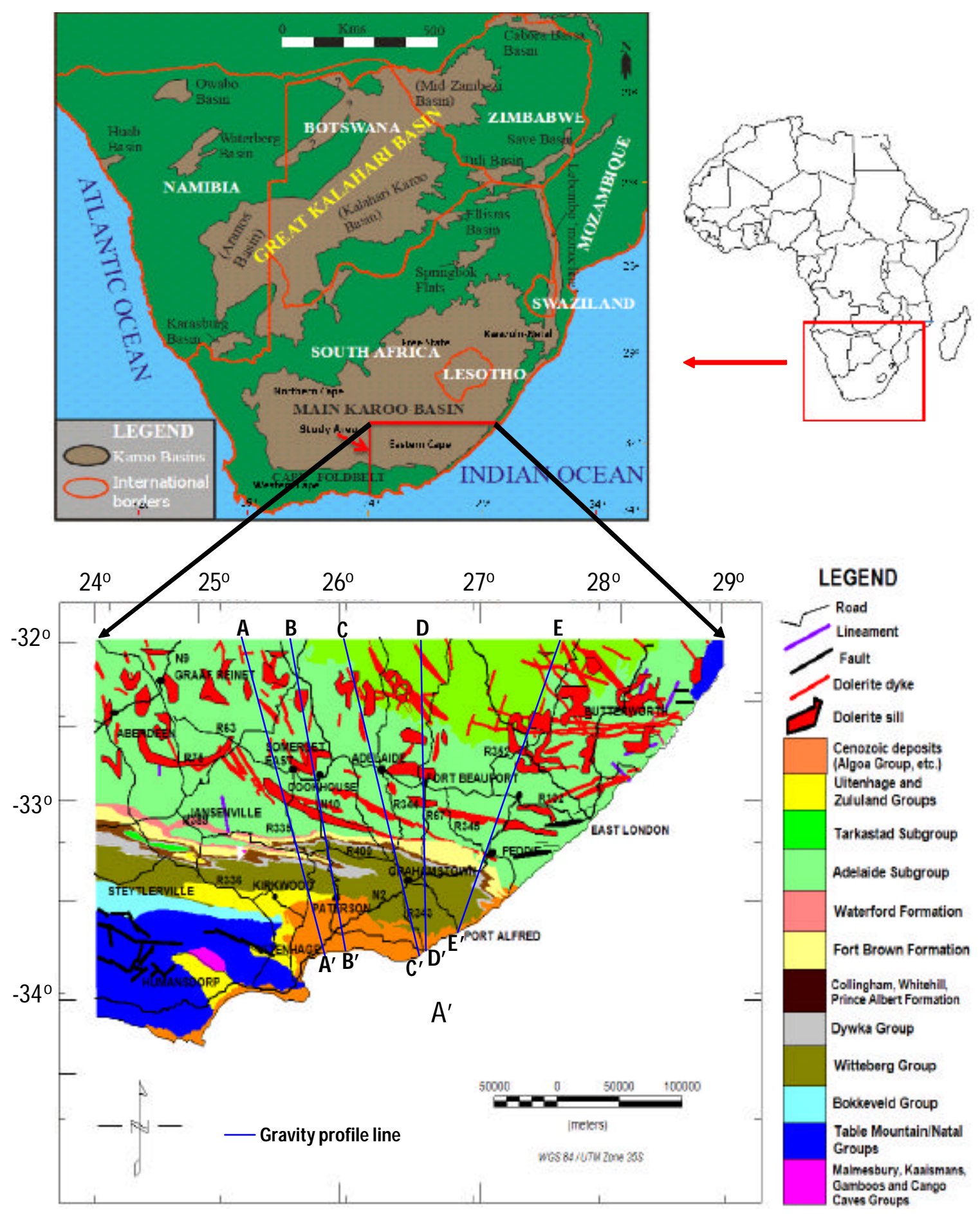

Fig. 1: Geological map of the study area. The map also shows the location of the Main Karoo Basin, subsidiary basins in Southern Africa and dolerite intrusions (Johnson et al., 2006)

Formations). The interpretation documented by Kingsley (1981) and Cole (1992) was contested by Johnson (1991) who envisaged that during the Triassic, a Southern magmatic arc located South of Cape Fold Belt also serve as an superfluous source area for the sediments of the Stormberg Group. 


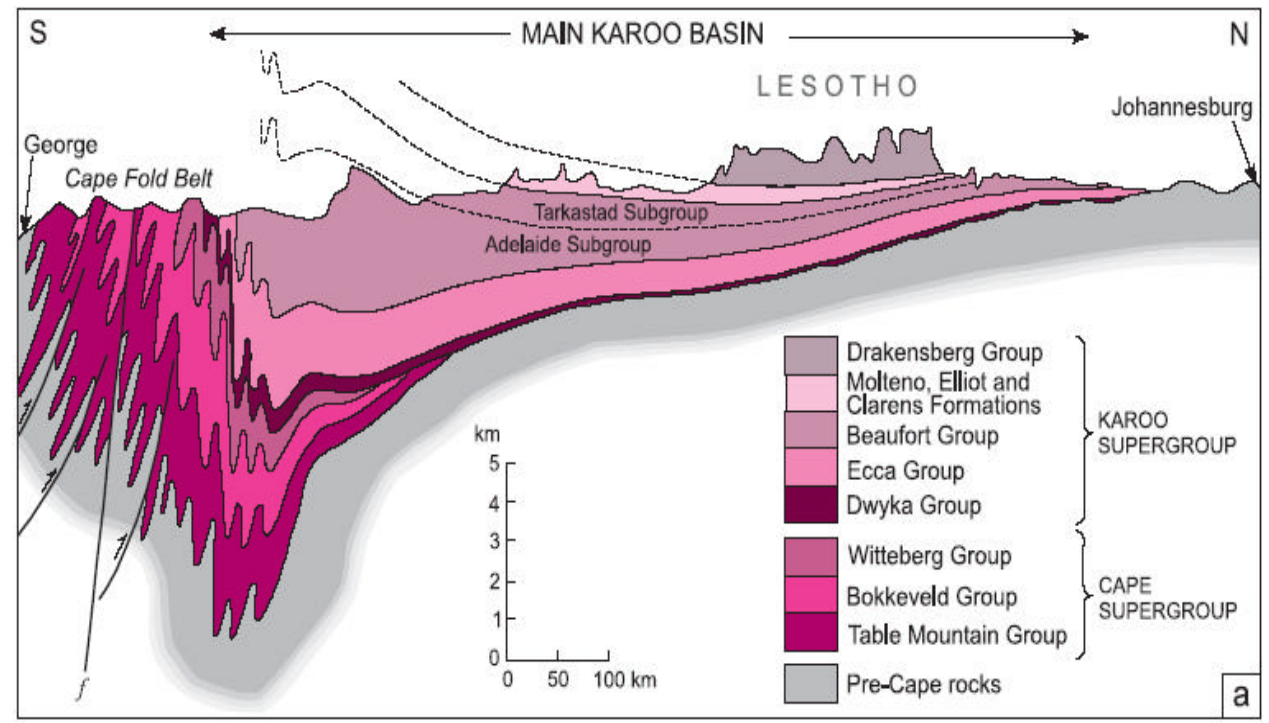

Fig. 2: Section view of Karoo Supergroup, showing the thinning effect and the tectonic settings (Johnson et al., 1997)

\section{MATERIALS AND METHODS}

Geophysical data and enhancement: Aeromagnetic and gravity data were obtained from Fugro Airborne Surveys (FAS) and the Council for Geoscience South Africa (CGS), respectively. Temporal magnetic variation and IGRF were both removed from the magnetic data in order to have signatures that are only due to the crustal magnetic field. Likewise, the gravity data were reduced or corrected to the Bouguer gravity values. The magnetic data was Reduced To The Pole (RTP) and Geosoft Oasis Montaj was used calculate radially averaged power spectrum. Getech Getgrid was used to compute the magnetic depth slicing. The magnetic results are displayed as geophysical maps.

Rock densities: Two hundred and eighty-nine rock samples were collected from road-cut outcrops of several formations of the Karoo and Cape Supergroups within the study area. The samples range from diamictite, shale, sandstone, mudstone, quartzite, limestone, chert, schist and conglomerate. The densities of rocks were obtained using the Archimede's principle in the laboratory.

$2 \frac{1}{2} \mathrm{D}$ gravity modelling: The gravity profiles (A-E) traversing the study area (Fig. 1) were modelled using the GM-SYS in Geosoft Oasis Montaj. The GM-SYS software works on the methods of Talwani et al. (1959) and utilizes the algorithms described in Talwani and Heirtzler (1964), Won and Bevis (1987) to calculate the gravity response. It also allows the model to extend to infinity at both ends, (i.e., $\pm 20000 \mathrm{~km}$ ), hence eliminating edge effects. The modelled profiles were selected to cut across the formations of the Karoo Supergroup as well as run parallel and very close to the roads where rock samples were taken for density measurement. The exact profile lengths and distance to each formation (outcropping to the surface) within and outside the area were measured on the geological map (Fig. 1). Fifteen models were generated and interpreted from the 5 profiles, 3 models per profile using the lowest, average and highest density values. Each model was created in GM-SYS by extracting Bouguer gravity and elevation values along the selected profile. More details on the modelling procedures can be found in Baiyegunhi (2015), Baiyegunhi and Gwavava (2017). The measured elevation, stratigraphic thickness and average density of Karoo and Cape Supergroups rocks that outcrop in the area were used to constrain the models. In the study area, a Moho depth ranging between 44-50 and 40-45 km has been indicated by Tedla et al. (2011), Stankiewicz and de Wit (2013), respectively. In this study, the Moho depth was originally set at $35 \mathrm{~km}$ and allowed to vary to about $55 \mathrm{~km}$ during the process of modelling. This was done to allow the model to compute the best fit/possible depth for the Moho. The thicknesses of the dolerites were extracted from Chevallier et al. (2001) and used for modelling. Just as the Moho, at the start or beginning of the modelling, the dolerites dykes and sills were put in vertical and horizontal positions, respectively and allow varying as modelling proceeds. The difference in density between the basement rocks and dolerite intrusions is very small such that for modelling purpose, intrusions in the basement were taken to be part of the basement. Thus, although, the intrusions appear to 
J. Eng. Applied Sci., 14 (6): 1885-1911, 2019

Table 1: Measured densities used for modelling

\begin{tabular}{lllllllc}
\hline Variables & Beaufort & Ecca & Dwyka & Cape & Dolerite & Basement & Below the Moho (Mantle) \\
\hline Lithology & Sandstone/Mudstone & Mudstone & Diamictite & Sandstone & Dolerite & $\begin{array}{l}\text { Chert/ } \\
\text { Schist }\end{array}$ \\
& & & & /Conglomerate & & - & - \\
No. of samples & 85 & 76 & 20 & 42 & 36 & 30 & - \\
Highest density $\left(\mathrm{g} / \mathrm{cm}^{3}\right)$ & 2.77 & 2.78 & 2.68 & 2.72 & 2.83 & 2.82 & 3.40 \\
Lowest density $\left(\mathrm{g} / \mathrm{cm}^{3}\right)$ & 2.27 & 2.35 & 2.59 & 2.63 & 2.71 & 2.72 & 3.14 \\
Average density $\left(\mathrm{g} / \mathrm{cm}^{3}\right)$ & 2.52 & 2.57 & 2.66 & 2.68 & 2.77 & 2.77 & 3.27 \\
\hline
\end{tabular}

terminate at the top of the basement they do extend into the basement. In order to test the sensitivity of the models to density changes, the highest and lowest density values in Table 1 were also used to get alternative models for all the profiles. Since, a total of 15 models were generated, only models that were generated using the average densities are shown in this study. The other models were only used to test the model's sensitivity in terms of variation in sedimentary layer thicknesses and densities.

Electrical resistivity: Electrical resistivity survey was carried out to investigate lateral and vertical variations in subsurface resistivity of the Ecca Group and also to detect bodies of anomalous electrical conductivity. Sites for the surveys were selected in areas where the Ecca Group formations which are the targeted geologic formations for shale gas exploration are exposed to the surface. The survey began with Horizontal Resistivity Profiling (HRP) using the Wenner array configuration. A current electrode spacing of $\mathrm{AB}=27 \mathrm{~m}(\mathrm{a}=9 \mathrm{~m})$ was chosen for the HRP survey such that the lower Ecca Group formations with a small outcrop thickness of about $28 \mathrm{~m}$ would be sampled, i.e., at least one measurement with AB fully within the outcrop. Thirt-two resistivity profiles of various lengths were carried out alongside the roads. In addition, a total of $37 \mathrm{VES}$ sites were carried out in the area. The VES current electrode spacing were chosen such that there were 6 logarithmically spaced intervals in a decade resulting in $\mathrm{AB}$ spacing ranging from $3-200 \mathrm{~m}$ (i.e., $\mathrm{AB} / 2=1.5-100 \mathrm{~m}$ ). The potential electrode spacing (MN) was $1 \mathrm{~m}$ throughout the soundings (i.e., $\mathrm{MN} / 2=0.5 \mathrm{~m}$ ). An appropriate geometric factor was applied to the recorded measurements of the potential difference $\Delta \mathrm{V}$ and current I to calculate the apparent resistivity $\left(\rho_{a}\right)$ of the subsurface for the HRP and VES data. Profiles of the HRP data were generated in Geosoft Oasis Montaj Software (Version 8.2.0.4) to display the lateral resistivity variations of the geologic formations. On the other hand, the VES data were initially inverted using the Software IPI2WIN (Version 2.1) developed by Alexey Bobachev, Moscow State University, Russia. This software iteratively generates a model that has a least Root-Mean Square (RMS) error between the calculated resistivity of the model and the actual field data (observed curve). When this was achieved, the observed geoelectric properties are considered to represent the subsurface geology and the iterated results were accepted and saved as RES2DINV file format that can be read in RES2DINV inversion software. Several single site modelled data exported from the IPI 2 WIN were combined into a pseudosection and further modelled in RES2DINV to generate a 2-D Model for the subsurface. In this study, the original model is iterated until the RMS value falls below the desired threshold which is less than $5 \%$ threshold. After this is achieved, the iterative process is stopped and the results saved as the final model. The HRP data is displayed as either a single profile or several profiles are used to generate profiling contour map (isoapparent resistivity map), then interpreted quantitatively. The VES single site data are displayed as sounding curves which are obtained by plotting graphs of $\log$ apparent resistivity $\left(\rho_{\mathrm{a}}\right)$ versus $\log$ of half electrode spacing $(\mathrm{AB} / 2)$. Furthermore, the apparent resistivity data for several sites are plotted as pseudosections in order to give an approximate picture of the true subsurface resistivity distribution. Thus qualitative interpretation is done in the case of VES data to determine the thickness, nature and lateral variations of the geological formations. A number of VES curves are published for comparison(Telford et al., 1990). These curves include simple curves for 2-5 layer cases and this aid the interpretation of the geoelectric models.

\section{RESULTS AND DISCUSSION}

Magnetic result: Three main magnetic anomalies are present in Fig. 3. The first anomaly which coincides with the Beattie Magnetic Anomaly (BMA) depicts that the anomaly is part of the BMA and extends from West of Somerset East to the North of Fort Beaufort. This anomaly with the highest magnetic value of approximately $906 \mathrm{nT}$ is thought to be as a result of a buried body underground that is rich in magnetic minerals. In addition, the centre or middle of the anomaly divides into two, suggesting that the body splits into two, nonetheless it still runs in the Northeast-Southwest direction. Another magnetic anomaly is present North-East of Butterworth (Fig. 3). This anomaly is of quite small with highest magnetic value of up to $240 \mathrm{nT}$. The anomaly could be as a result of dolerites with accompanying faulting that are visible 
North and North-East of Fort Beaufort (Fig 3). The third anomaly has a shape that looks like a bean, thus, it is refer to as "bean shape anomaly". The anomaly extends from North of Cookhouse (Long. 26E; Lat. 33 ${ }^{\circ} \mathrm{S}$ ) to North-East of Peddie (Long. $27^{\circ} \mathrm{E}$; Lat. $33^{\circ} \mathrm{S}$ ) and has maximum magnetic value of about $120 \mathrm{nT}$. The prominent magnetic signatures (ring and linear shaped signatures), particularly on the Northern and Eastern side of Fort Beaufort are believed to be due to highly magnetic Karoo dolerite intrusions.
Power spectrum and depth slicing: The power spectrum was calculated to estimate the average depth to magnetic sources. The approximated magnetic depth ( $\mathrm{h}=$ Slope $/-4 \pi$ ) of about $700 \mathrm{~m}$ and up to $15,100 \mathrm{~m}$ were calculated (after subtracting the flight height) from the slope as the depth to the upper part (top) of the shallow and deep seated magnetic sources, respectively (Fig. 4). The anomaly amplitude reactions or responses at specific depths were noted by comparing the depth slices (Fig. 5). Consequently, the appearance and disappearance of

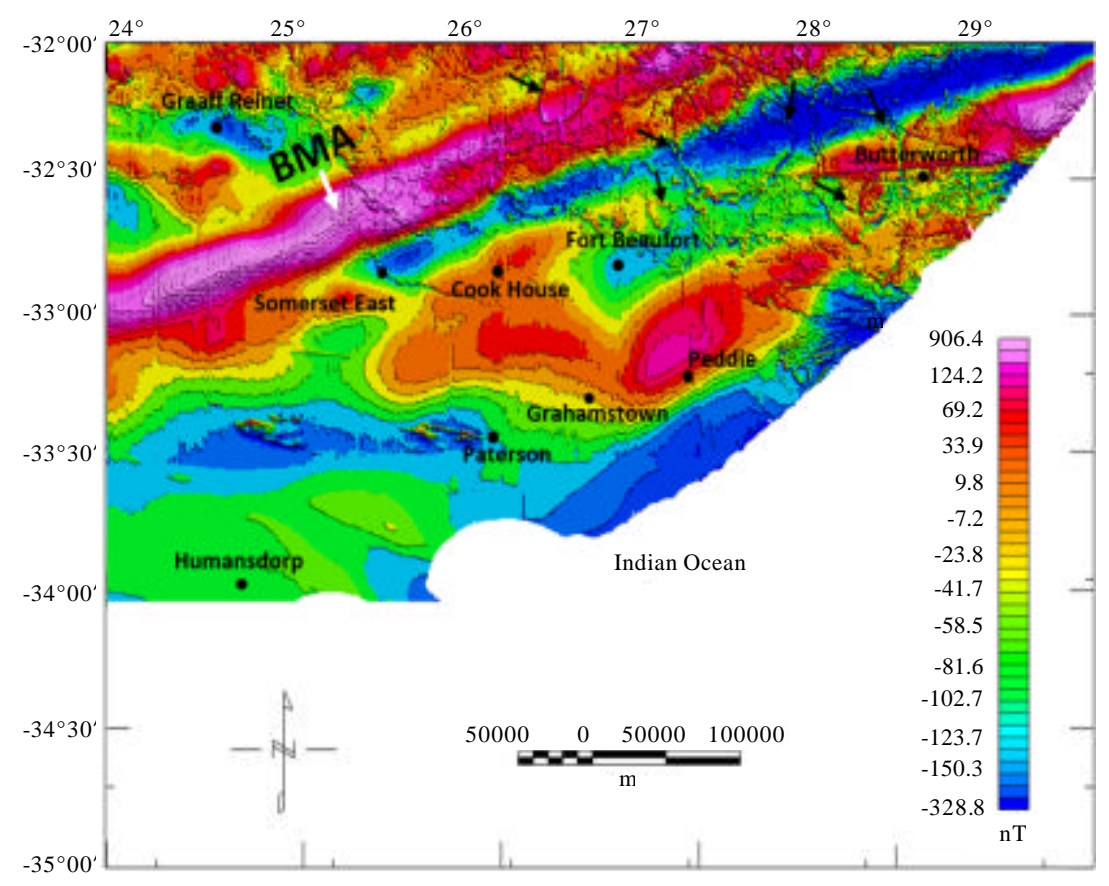

Fig. 3: Reduced to the Pole (RTP) magnetic residual anomaly map. The black arrows point to circular or ring structures which are some of the dolerite sills

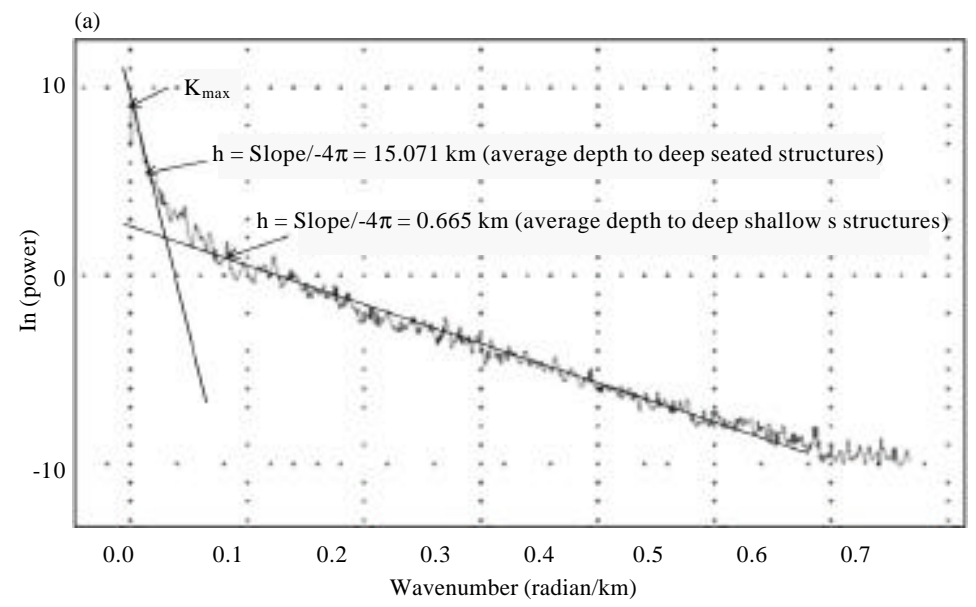

Fig. 4: Continue 
(b)

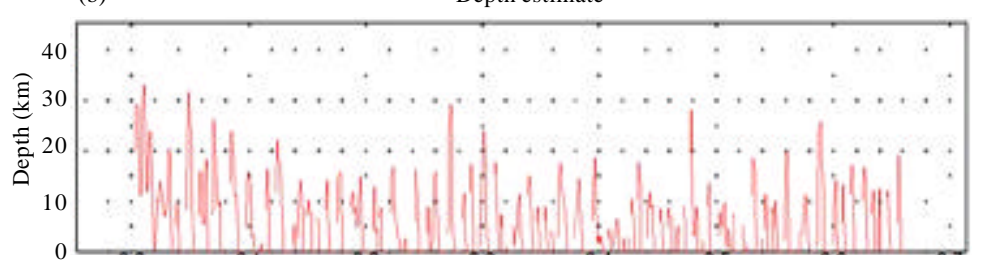

Wavenumber (radian/km)

Fig. 4a, b): Radially averaged power spectrum showing the depth estimate
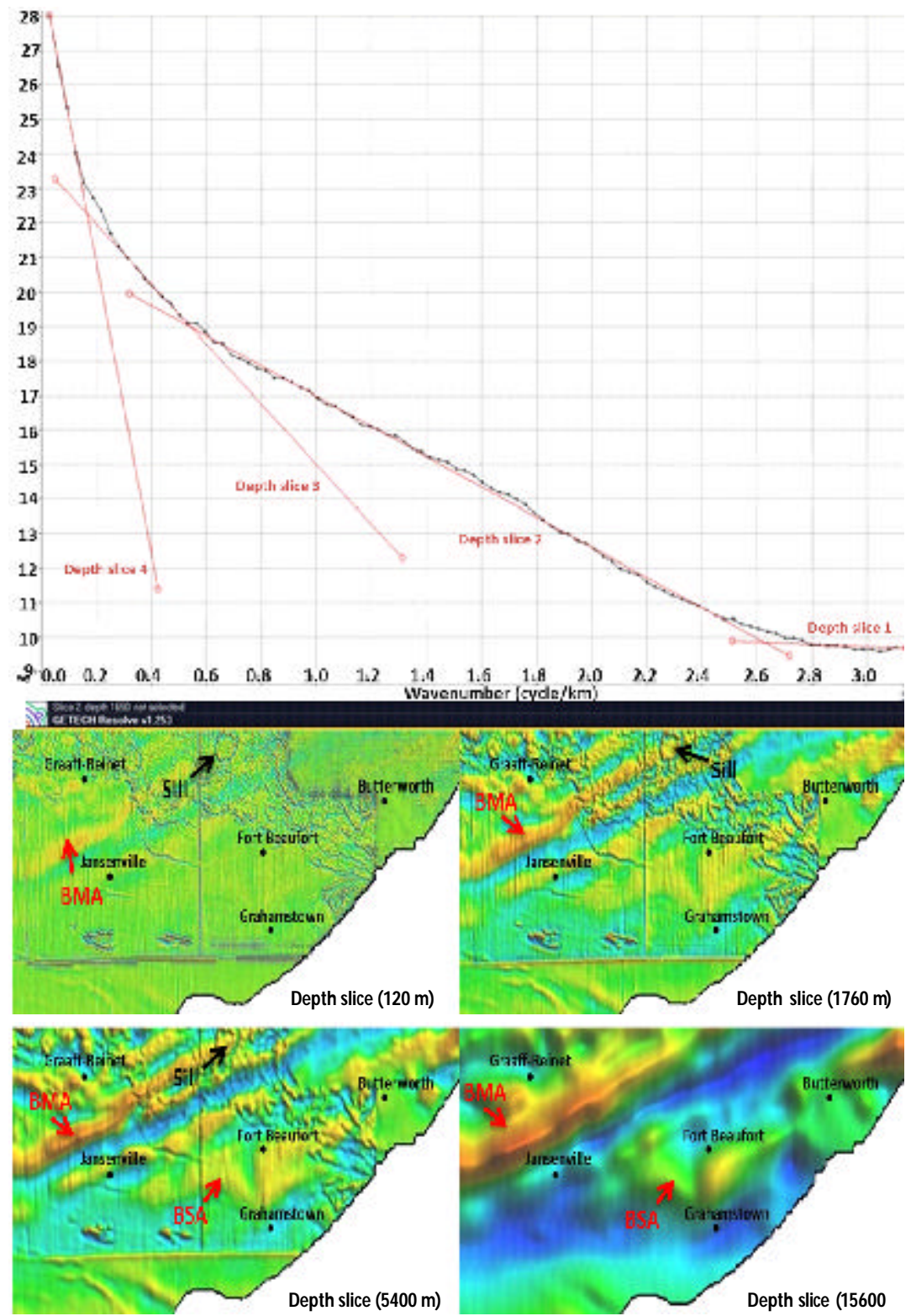

Fig. 5: Depth slices showing the appearance and disappearance of anomalous features with depth. The BMA and BSA represent the Beattie magnetic anomaly and the bean shape anomaly, respectively 


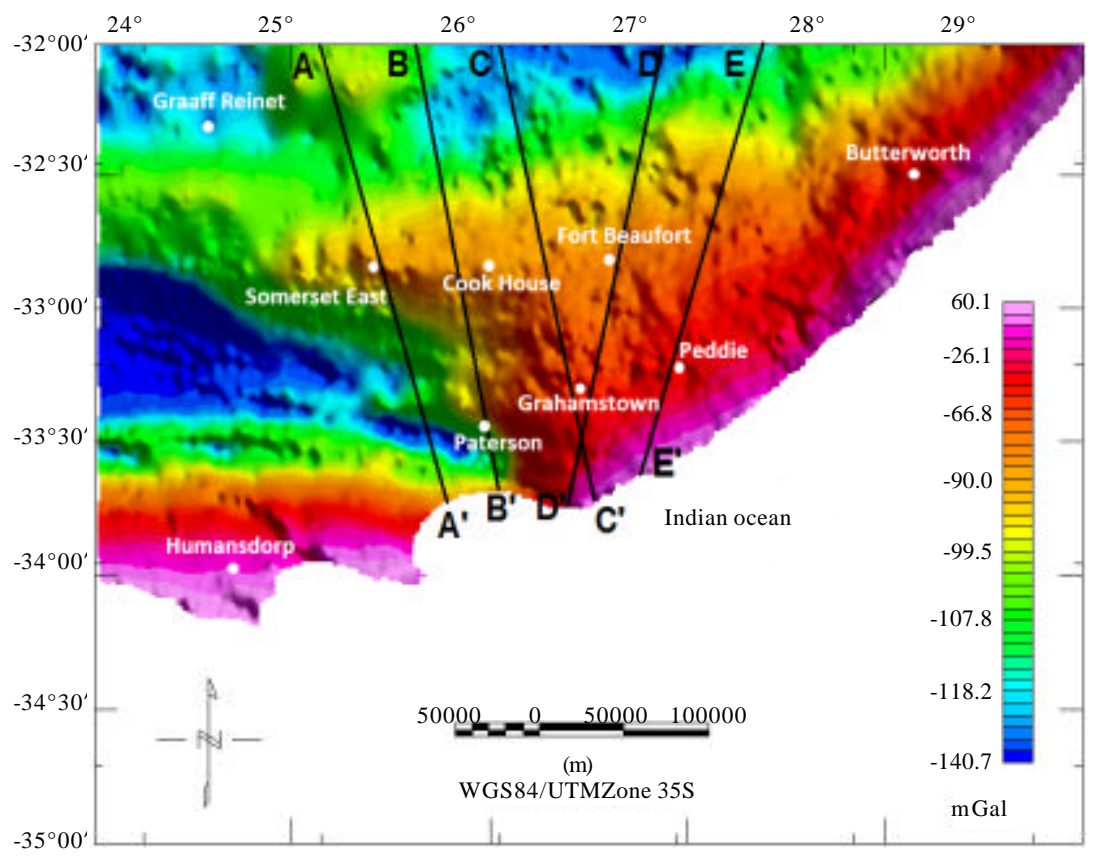

Fig. 6: Bouguer anomaly map

anomalous signatures at a specific depth were known. Depth slices 1-3 revealed structural patterns that overlap with dolerites on the geological map of the area. Depth slices 1-3 also show that the mapped intrusions (dolerites) have responses that are noticeable until a depth of approximately $5400 \mathrm{~m}$ (Fig. 5). By comparing depth slice 4 and other depth slices, depth slice 4 revealed only little or no anomalies that are due or can be linked to the mapped dolerite intrusions. A dolerite sill with a circular or ring structure was observed in the Northern part of the map (Fig. 5). This ring structure becomes stronger and more visible as the depth increases to about $5400 \mathrm{~m}$ but disappears on depth slice 4 which depicts magnetic signatures at a depth of $15600 \mathrm{~m}$.

Gravity: The Bouguer gravity anomaly map depicted in Fig. 6 shows gravity values increasing from around -141 $\mathrm{mGal}$ in Graaff-Reinet and Somerset East areas (inland) up to approximately $60 \mathrm{mGal}$ far South of Peddie, Butterworth and Humansdorp (coastal areas). The main gravity highs observed far South of Peddie, Butterworth and Humansdorp (coastal areas) are thought to be of long wavelength. This is perhaps as a result of deeper source (s) like the Moho that shallows Southward towards the coast (Fig. 7). The low gravity values in inland areas (around Graaff-Reinet and Somerset East) are of short wavelength, perhaps resulting from shallow source bodies; e.g., Karoo dolerite intrusions.
Dry density: The observed gravity value depends on the time, latitude, elevation/height, topography and rock densities. Thus, these effects must be removed except the last one (rock densities), so that, only effects of geological features remain. The densities of the rock samples were calculated and presented in Table 1. The average densities measured for the formations range between $2.3-2.8 \mathrm{~g} / \mathrm{cm}^{3}$. These values falls within the range documented by Van der Voort (2001) that investigated the rocks of the Main Karoo Basin. The density values for rocks below the Moho were extracted from Cook et al. (2010), Mjelde et al. (2013), Thybo and Artemieva (2013).

$21 / 2 \mathrm{D}$ gravity profile models: The $2 \frac{1}{2} \mathrm{D}$ gravity models are presented in Fig. 7a-e. The modelled gravity profiles starts in the Karoo Basin and ends at the coast (Fig. 7). Figure $7 \mathrm{a}, \mathrm{b}$ shows the gravity modelling of profiles A-A' and $\mathrm{B}-\mathrm{B}$ ' that passes through an area of relatively low gravity values in the map (Fig. 6). The minimum and maximum gravity values along these profiles are about -138 and $-20 \mathrm{mGal}$, respectively. In the models, the layers, both the Cape and Karoo Supergroups have been intruded by dolerites (about $180 \mathrm{Ma}$ ) and show undulations which are inferred to be due to deformation. Evidence of faulting (lateral displacement) is also observed in the models. The Cenozoic deposits and the Uitenhage and Zululand Groups are present along profile A-A' and B-B' and their thicknesses also varies due to 

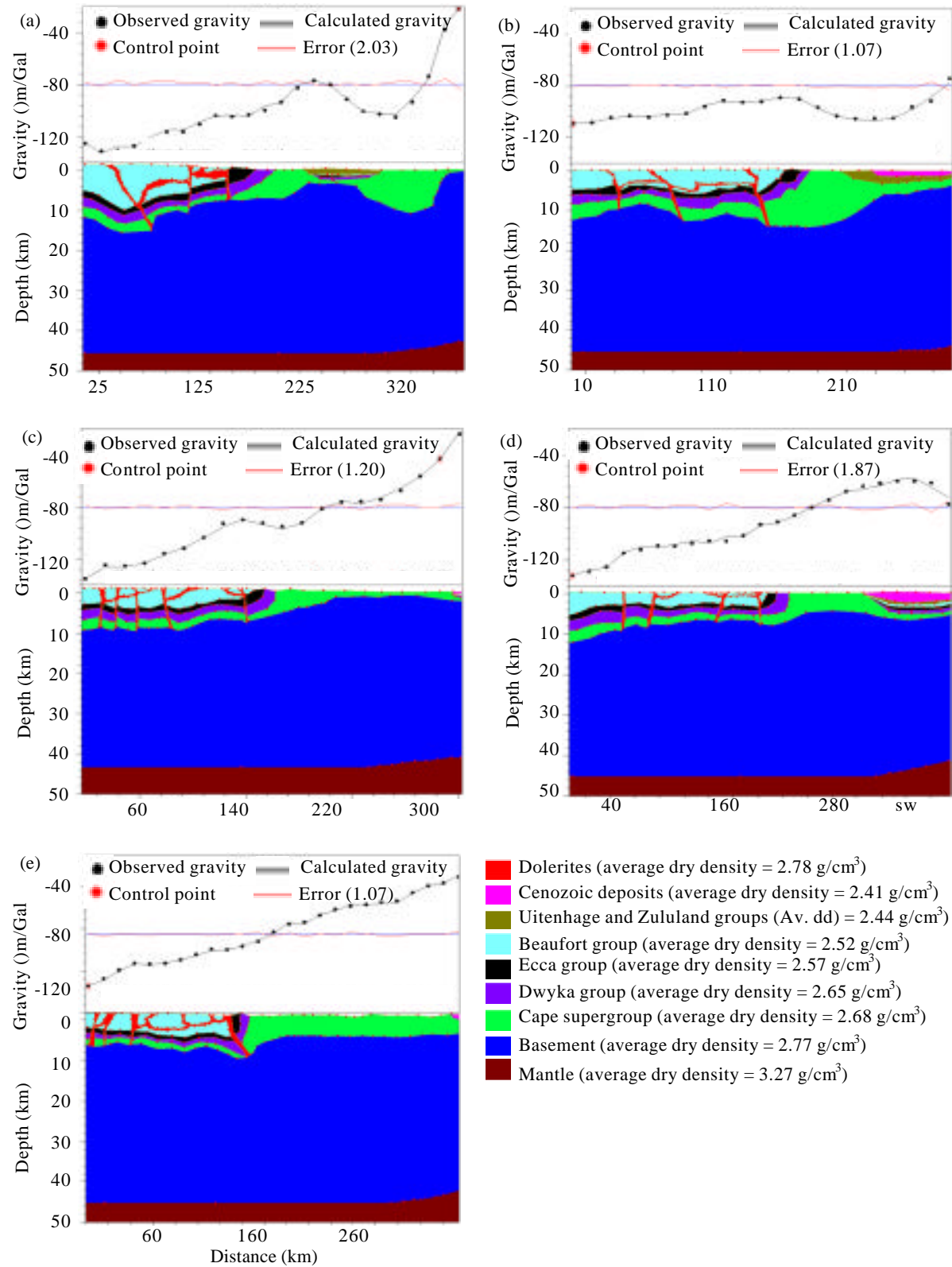

Dolerites (average dry density $=2.78 \mathrm{~g} / \mathrm{cm}^{3}$ )

Cenozoic deposits (average dry density $=2.41 \mathrm{~g} / \mathrm{cm}^{3}$ )

Uitenhage and Zululand groups $($ Av. dd $\left.)=2.44 \mathrm{~g} / \mathrm{cm}^{3}\right)$

Beaufort group (average dry density $=2.52 \mathrm{~g} / \mathrm{cm}^{3}$ )

Ecca group (average dry density $=2.57 \mathrm{~g} / \mathrm{cm}^{3}$ )

Dwyka group (average dry density $=2.65 \mathrm{~g} / \mathrm{cm}^{3}$ )

Cape supergroup (average dry density $=2.68 \mathrm{~g} / \mathrm{cm}^{3}$ )

Basement (average dry density $=2.77 \mathrm{~g} / \mathrm{cm}^{3}$ )

Mantle (average dry density $=3.27 \mathrm{~g} / \mathrm{cm}^{3}$ )

Fig. 7: Gravity modelling of profiles: a) A-A'; b) B-B'; c) C-C'; d) D-D' and e) E-E'. When the black line/curve (calculated gravity) matches with the black dots (observed gravity), it indicates a perfect fit with minimum error

deformation. Figure $7 \mathrm{c}$-e shows the gravity modelling results of profiles C-C', D-D' and E-E' that have increasing of gravity values from the NW-SE direction of the map (Fig. 6). The thickness of sediments in the Karoo and Cape Supergroups varies or differs along these profiles as a result of deformation as shown in the models. The sedimentary sequence of the Karoo Basin is intruded by dolerites with associated faulting as depicted in models (Fig. 7c-e). The intrusions (dolerites) that outcrop on the surface are observed in the model and they extend to depths that cuts through the Karoo and Cape Supergroup in the form of sills and dykes (Fig. 7c-e). The dykes acted or behave as feeders to the sills that are outcropping on the surface.

Electrical resistivity: The Ecca Group formations outcrop in the study area and are part of the targeted areas for petroleum exploration in South Africa. Electrical resistivity survey was carried out on the road-cut exposures of the Ecca Group (Fig. 8) in order to investigate lateral and 
vertical variations in resistivity of the subsurface layers and also to detect bodies of anomalous electrical conductivity.
Horizontal Resistivity Profiling (HRP): The HRP single profiles are presented in Fig. 9a-f. The maximum depth of penetration of the HRP using Wenner array is $1 / 3$

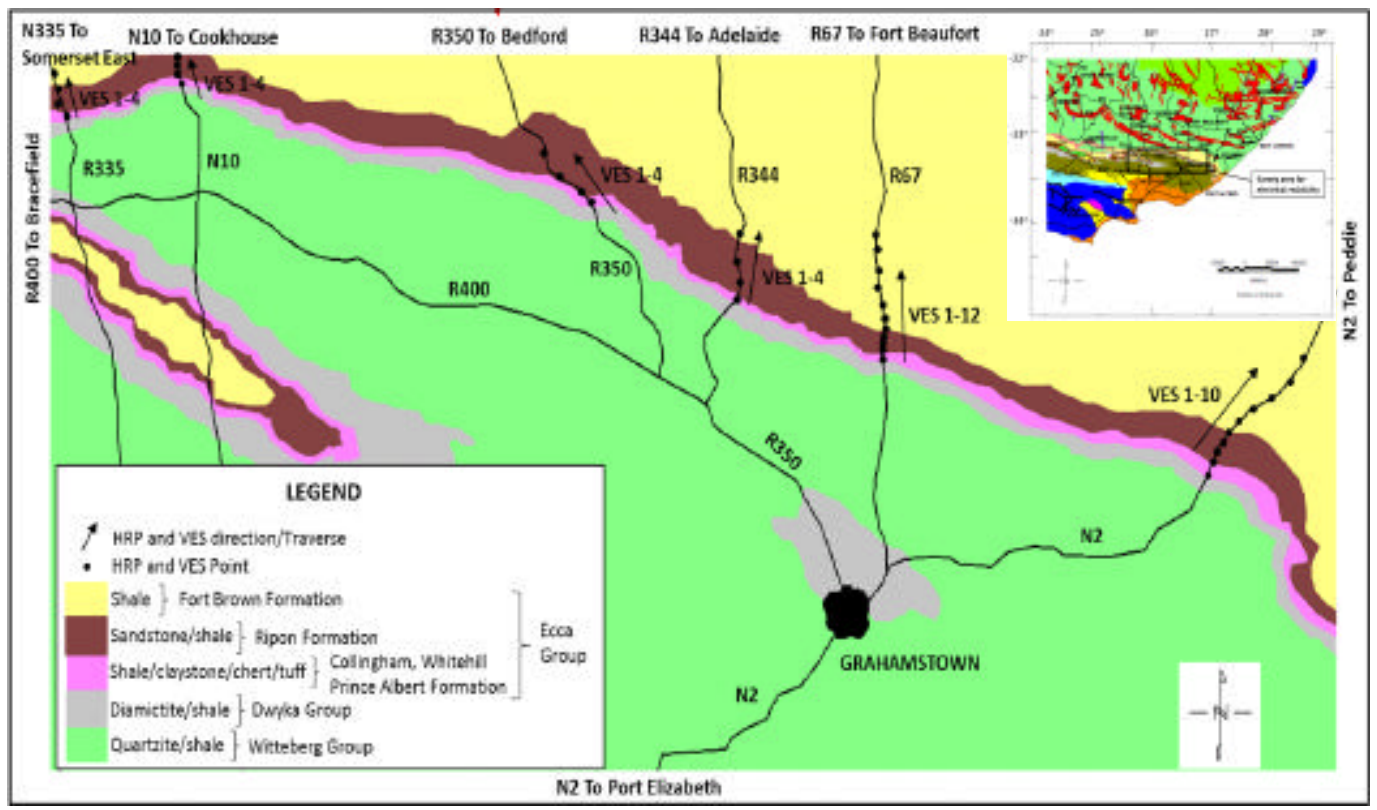

Fig. 8: Map of the study area showing HRP and VES points and direction. The HRP is horizontal resistivity profiling and VES is vertical electrical sounding

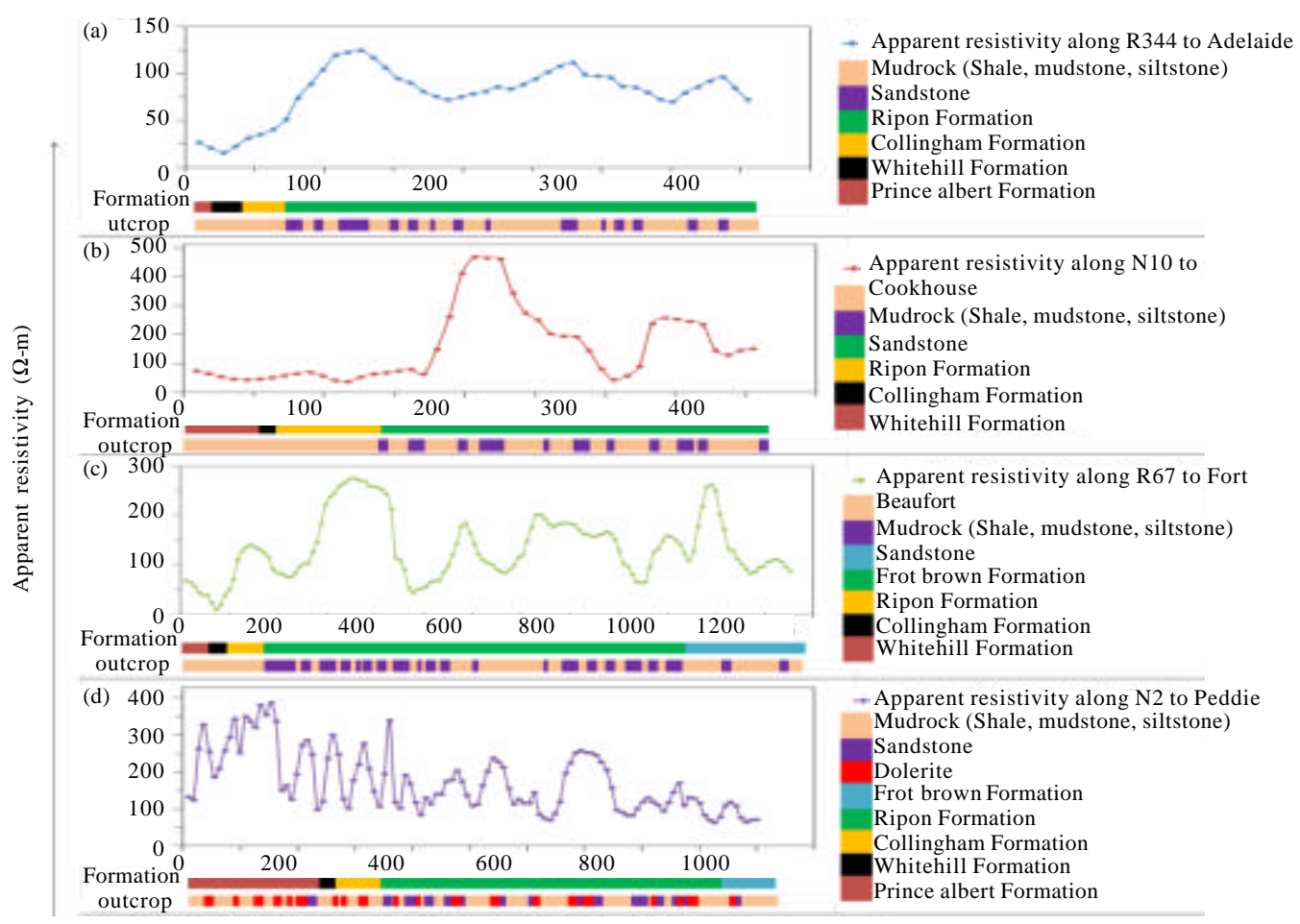

Fig. 9: Continue 


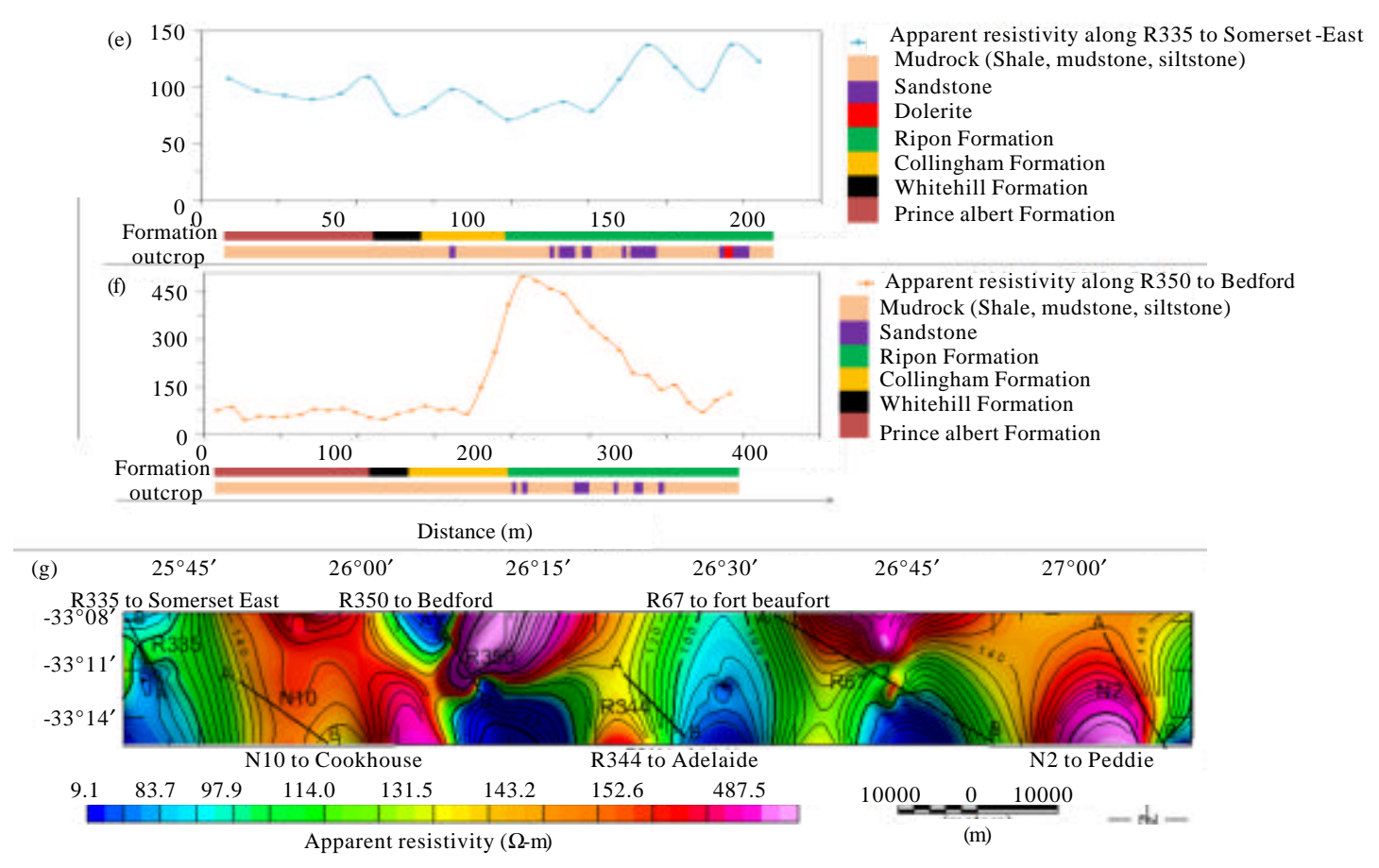

Fig. 9: Horizontal resistivity profiling survey on road-cut exposures of the Ecca Group showing lateral variation in the apparent resistivity at a depth of about $9 \mathrm{~m}$ : a-f) Graphs of apparent resistivity versus distance and g) Iso apparent electrical resistivity map of the combined or all the profiles

of the maximum distance of current electrodes (Frohlich et al., 1996). The current electrode spacing in the HRP survey is $27 \mathrm{~m}(\mathrm{a}=9)$, thus, the depth of penetration is $9 \mathrm{~m}$. The measured apparent resistivities along Regional roads R335 to Somerset East and R344 to Adelaide are generally low, ranging between 9.1 and $135 \Omega \mathrm{m}$ (Fig. 9a, e). The result of HRP along Regional road R350 to Bedford is shown in Fig. 9f. Along this profile (A-B), the resistivity value increases from about $70 \Omega \mathrm{m}$ at the start of the line to $500 \Omega \mathrm{m}$ at a distance of about $240 \mathrm{~m}$. Thereafter, the resistivity value decreases to $\sim 80 \Omega \mathrm{m}$ at a distance of about $300 \mathrm{~m}$ and slightly increases to $\sim 130 \Omega \mathrm{m}$ at the end of the line. The resistivity values measured along Regional road R67 between Grahamstown and Fort Beaufort (Ecca Pass) is characterized by heterogeneous resistivity or generally undulate with minimum and maximum resistivity values of about 10 and $275 \Omega \mathrm{m}$, respectively (Fig. 9c). The resistivity values along National roads N10 to Cookhouse and N2 to Peddie are fairly high, ranging from about 100 to $\sim 200 \Omega \mathrm{m}$ (Fig 9d). The isoapparent resistivity map (combined profiles map) is depicted in Fig. 9g. The map shows that apparent resistivity of the subsurface varies laterally between 2 and $500 \Omega \mathrm{m}$ in the study area. Since, current is conducted electrolytically by groundwater (in saturated layers) and dielectrically by effective surface of minerals (in dry layers) it is inferred that areas with low apparent resistivity values are possibly due to buried rock or soil with high clay and moisture and water content and vice versa.

\section{Vertical Electrical Sounding (VES)}

Geoelectric models: The VES curves and the best fitting models are depicted in (Fig. 10-15). The interpreted geoelectric sections are presented in Table 2-7 including the inferred lithology and curve types. The geoelectric sections depicted in Fig. 10-15, show four to five subsurface layers which include the topsoil, mudstone, sandstone, consolidated shale and dolerite intrusion. The topsoil is composed of dry sandy clay with resistivity values ranging between 34 and 844 $\Omega \mathrm{m}$. The thickness of this layer varies from 0.27-2.19 $\mathrm{m}$ being thinnest at VES 3 along Regional roads R335 to Somerset East and R350 to Bedford and thickest at VES 13 along Regional road R67 to Fort Beaufort. It is observed from the geoelectric sections that VES 1 and 2 along Regional road R335 to Somerset East, VES 1 along National road N10 to Cookhouse and VES 4 along Regional road R350 to Bedford are characterized with low resistivity values varying between 34-77 $\Omega \mathrm{m}$. These low resistivity values suggest that the topsoil in these areas possibly has high clay and/or moisture content. The wide range in the resistivity values 


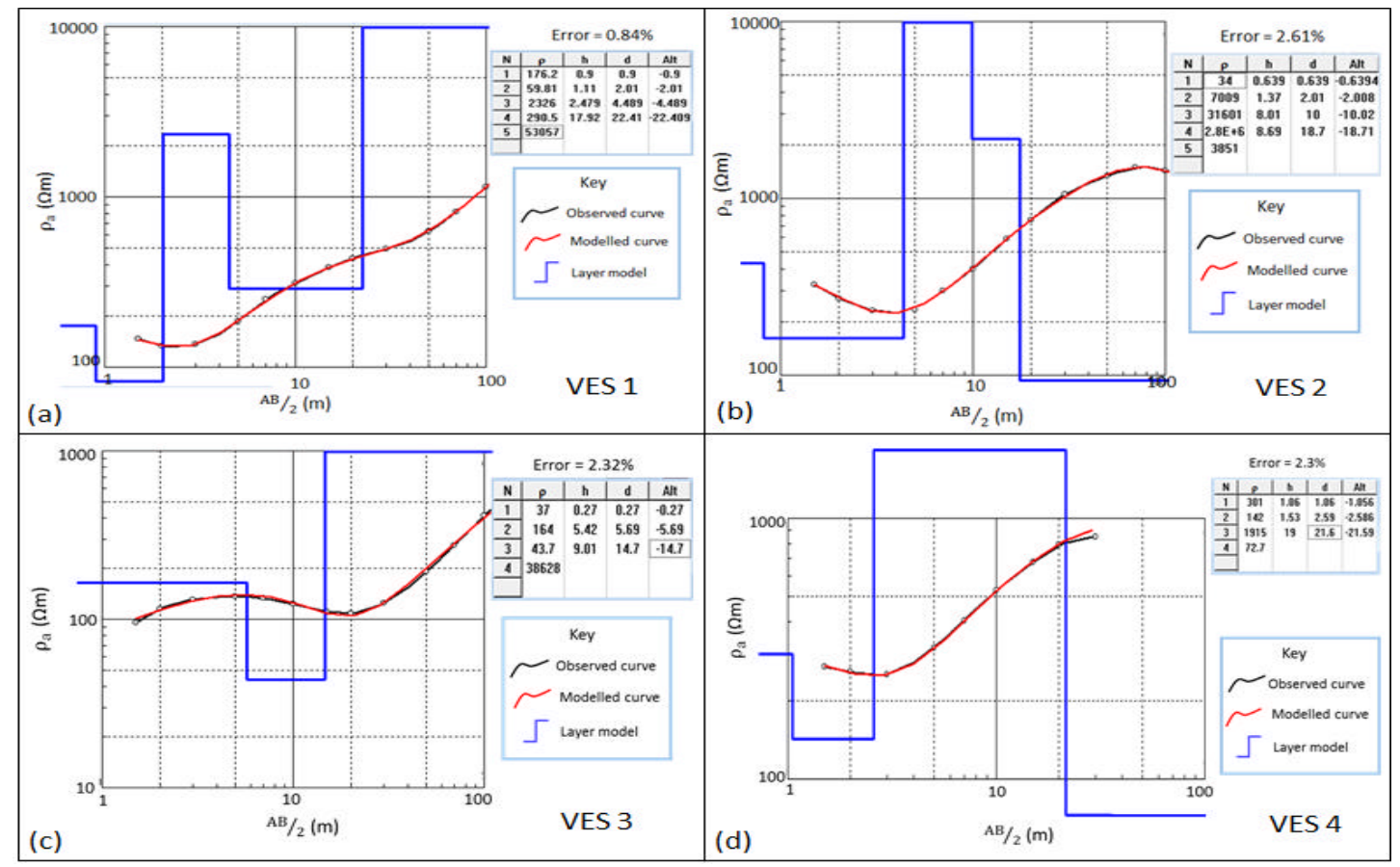

Fig. 10: VES curves and geoelectric models for four sites along Regional road R335 between Kirkwoood and Somerset East. N) The number of layers; $\rho$ ) The apparent resistivity for the layer; h) The layer thickness and d) The depth to the top of the layer

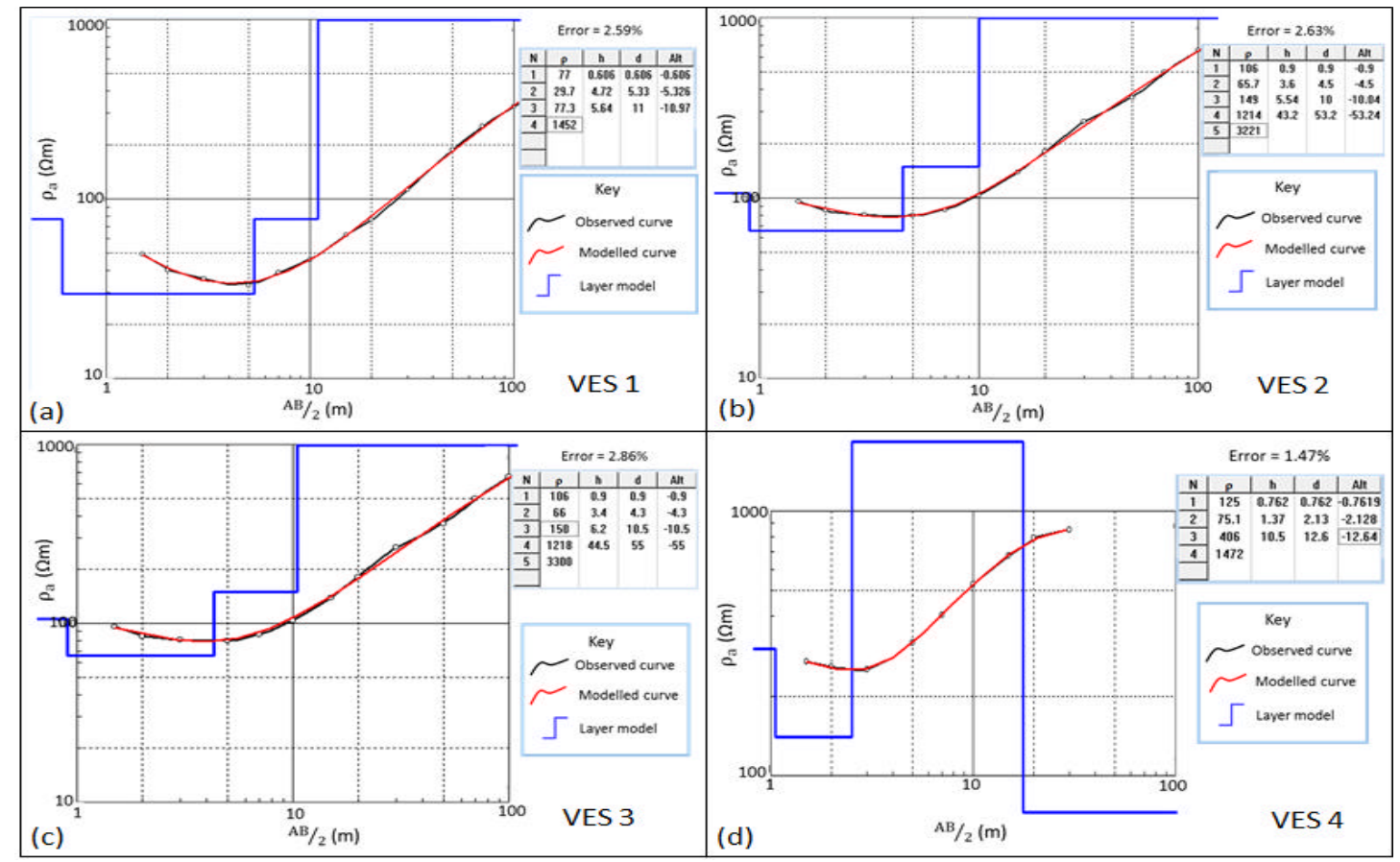

Fig. 11a-d): VES curves and geoelectric models for four sites along National road N10 between Cookhouse and Paterson

is possibly due to the different degree of compaction. The resistivity and thickness of the second layer varies from about 8 and $7009 \Omega \mathrm{m}$ and $0.62-5.42 \mathrm{~m}$, respectively. This layer is mostly inferred to be mudstone, although, in 


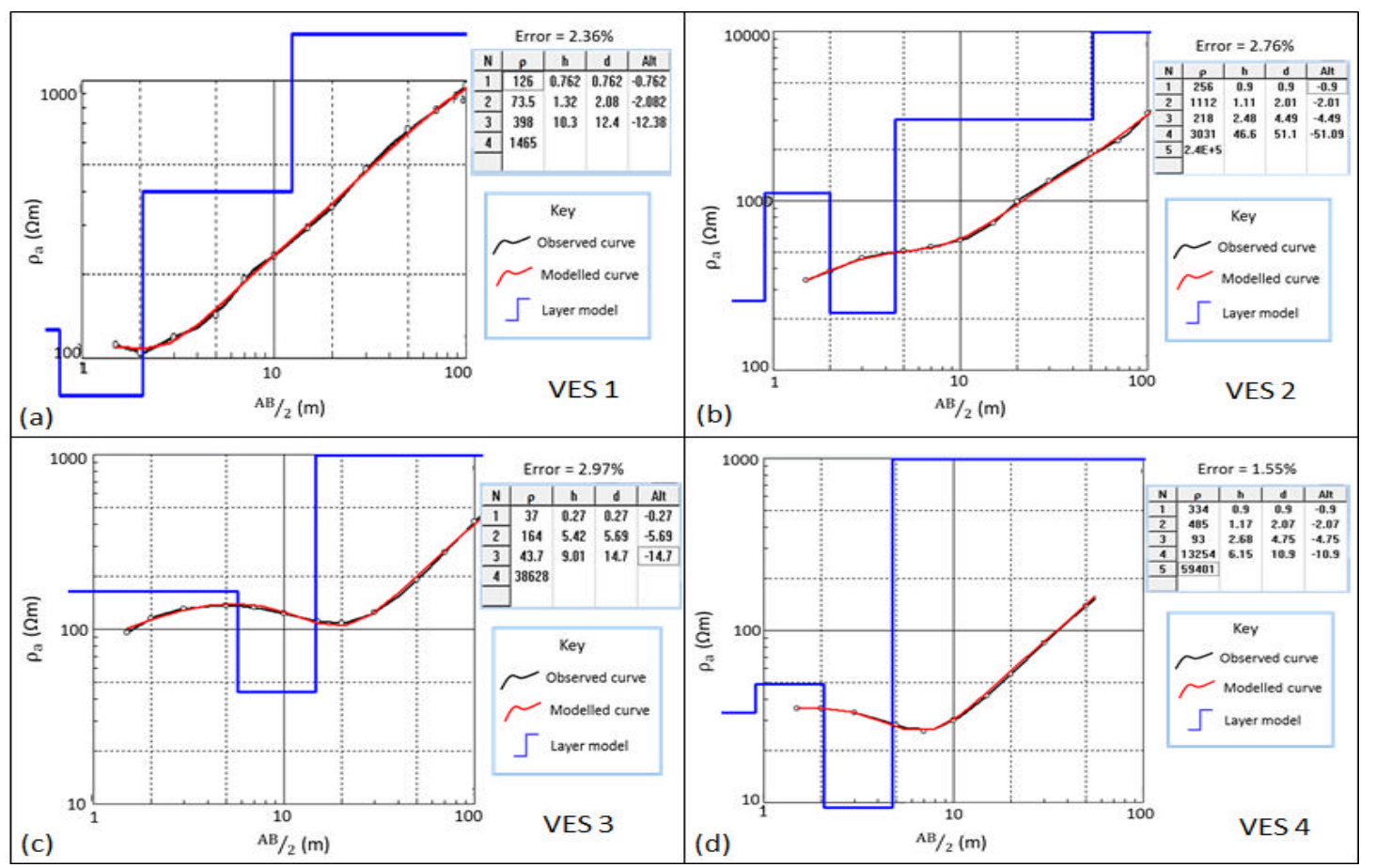

Fig. 12a-d): VES curves and geoelectric models for four sites along Regional road R350 between Bedford and Grahamstown
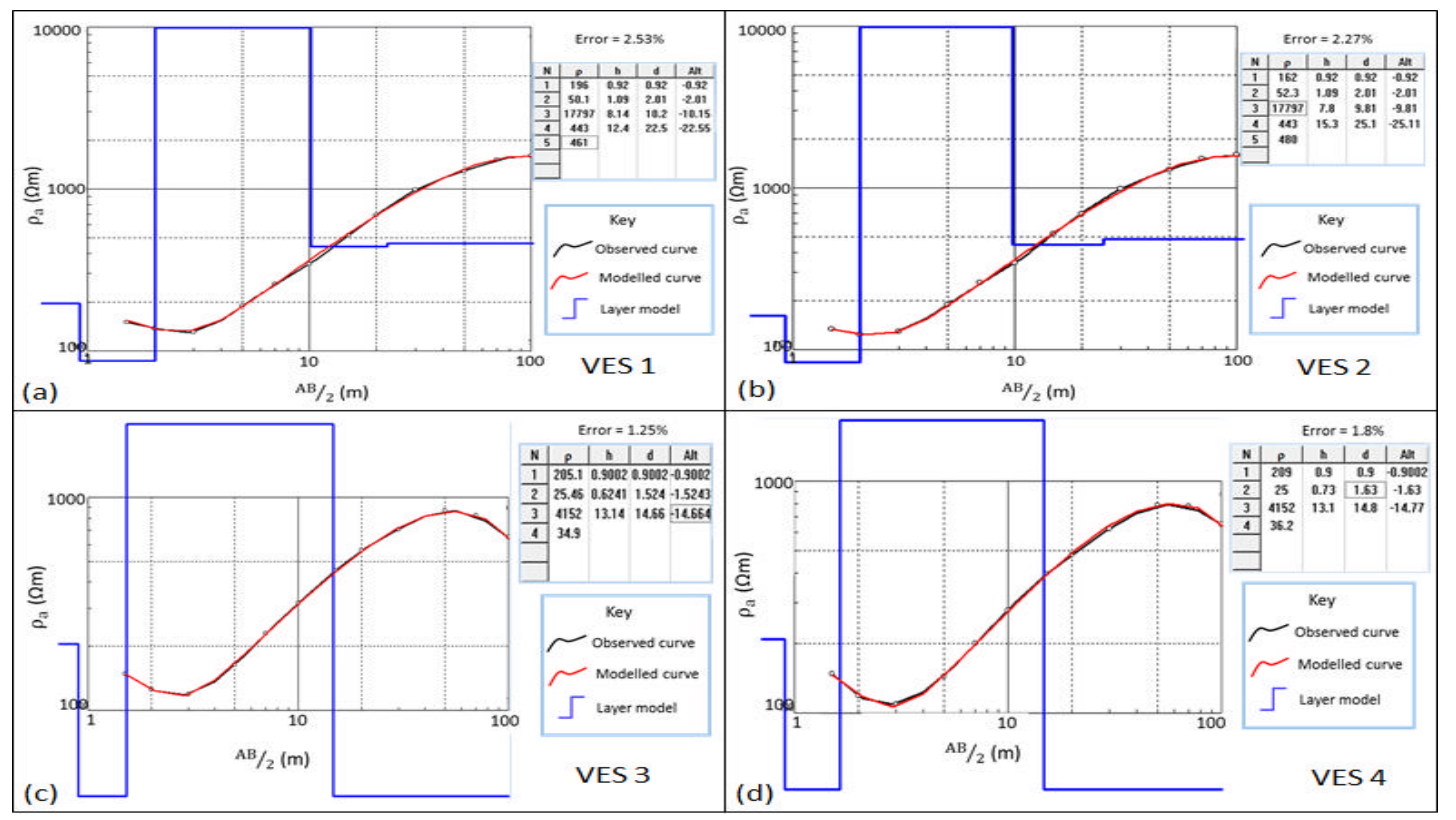

Fig. 13a-d): VES curves and geoelectric models for four sites along Regional road R344 between Adelaide and Grahamstown

some places it has been replaced by weathered sandstone. The second layer along Regional road R335 to Somerset East is weathered dolerite intrusion with resistivity values of about $7009 \Omega \mathrm{m}$. On the contrary, the apparent resistivity of the second layer (at VES 2) along Regional road R67 between Grahamstown and Fort Beaufort is $8 \Omega \mathrm{m}$ and it inferred to be clay. The resistivity and thickness of the third layer varies between 1and 31601 


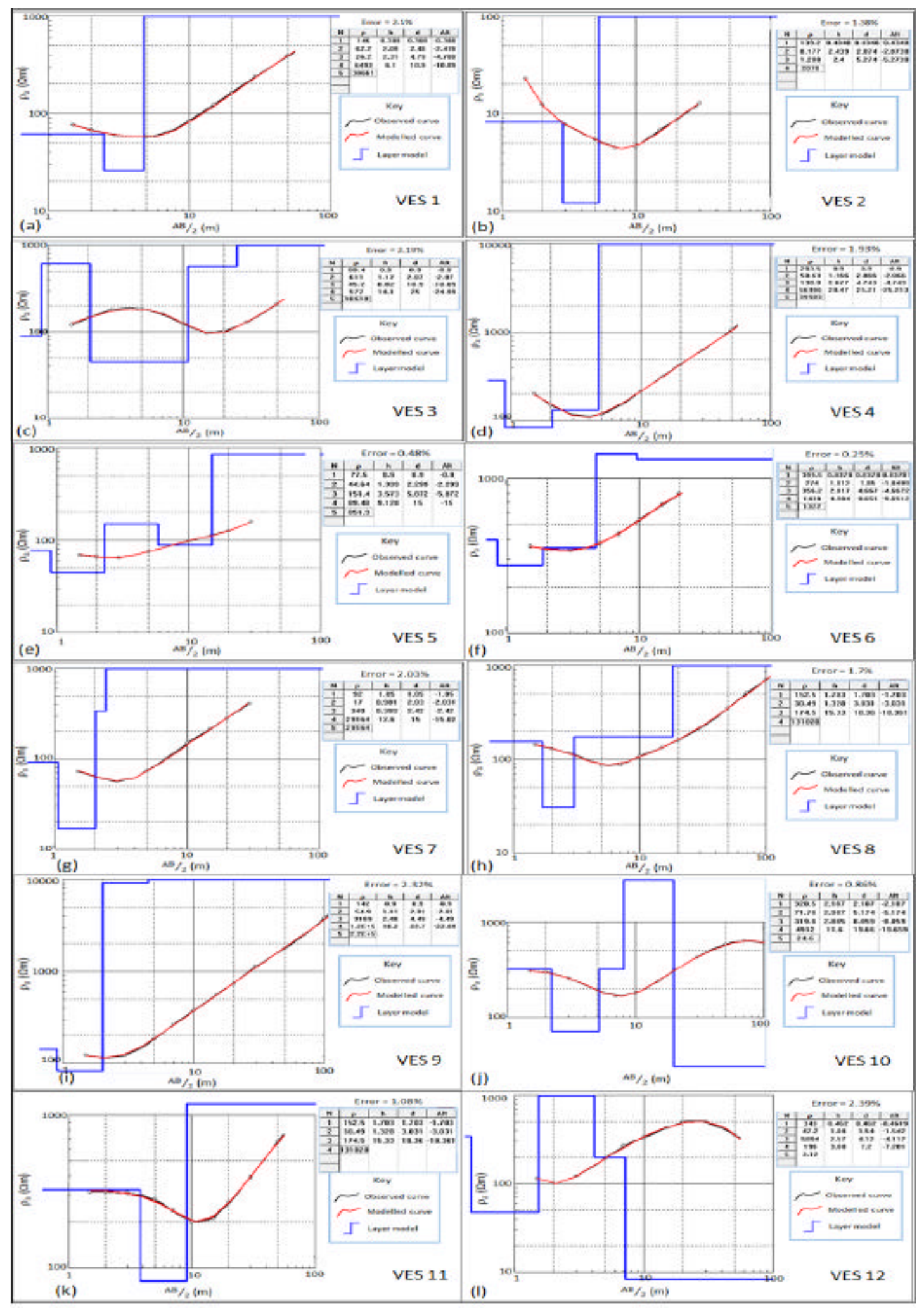

Fig. 14a-1): VES curves and geoelectric models for twelve sites along Regional road R67 between Grahamstown and Fort Beaufort (Ecca pass) 


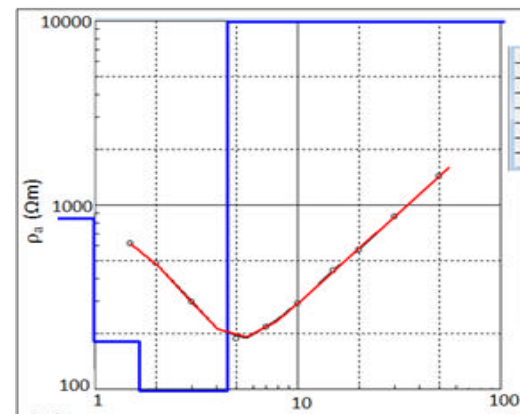

(a)

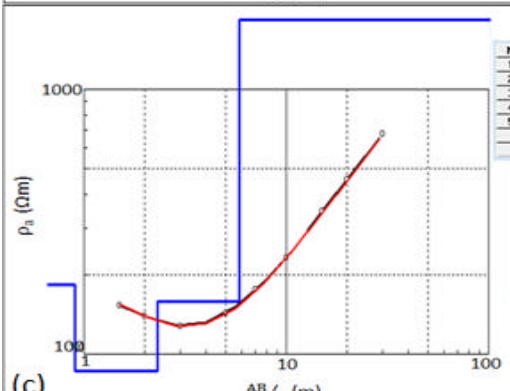

(c)

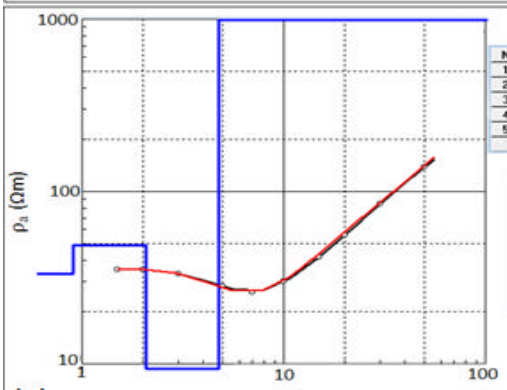

(e)

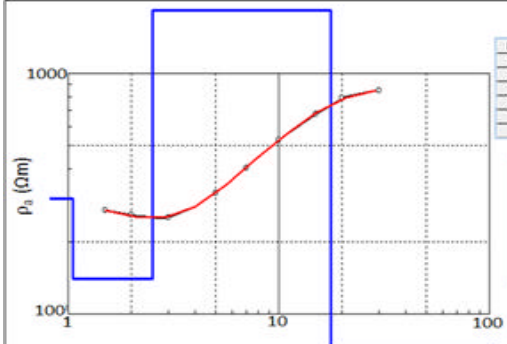

(g)

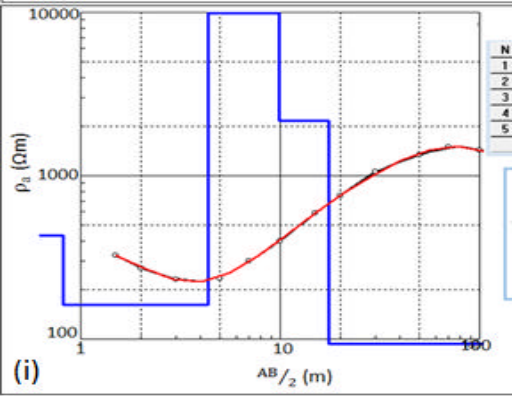

Error $=0.64 \%$

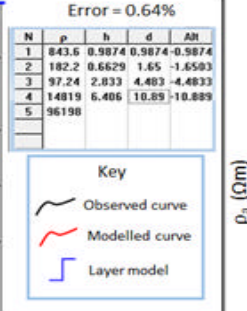

VES 1

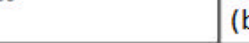

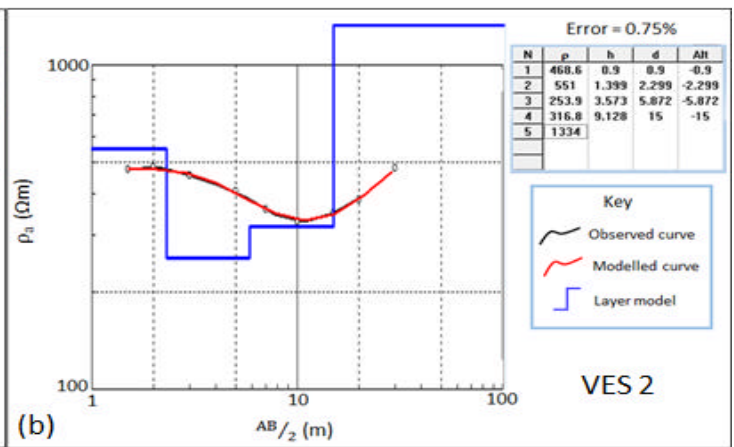

(b)

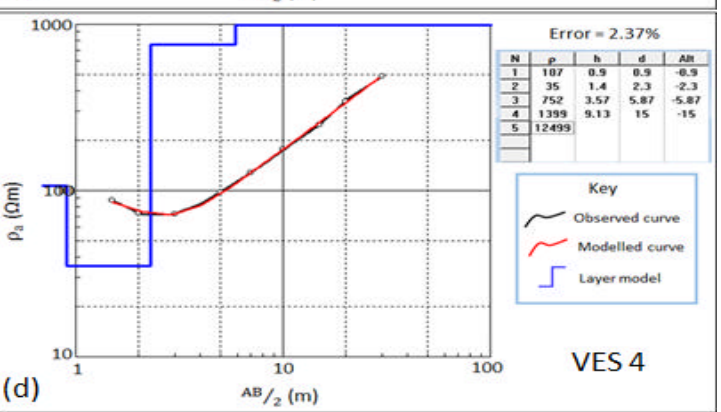

(d)
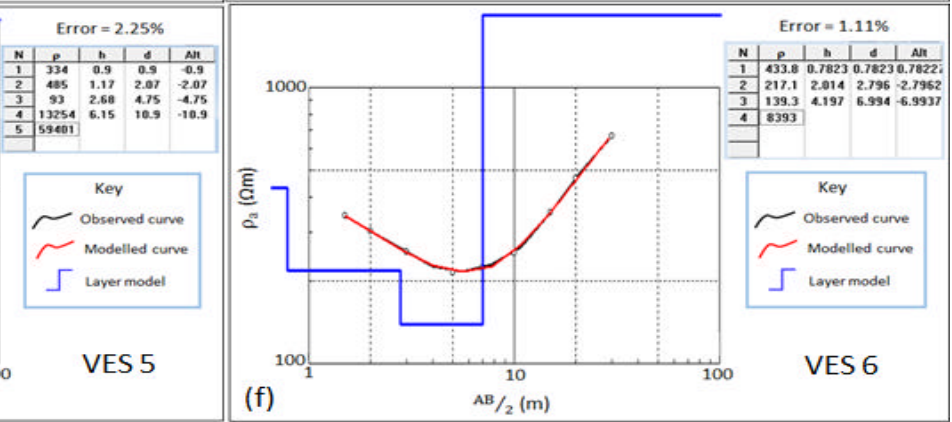

(f)

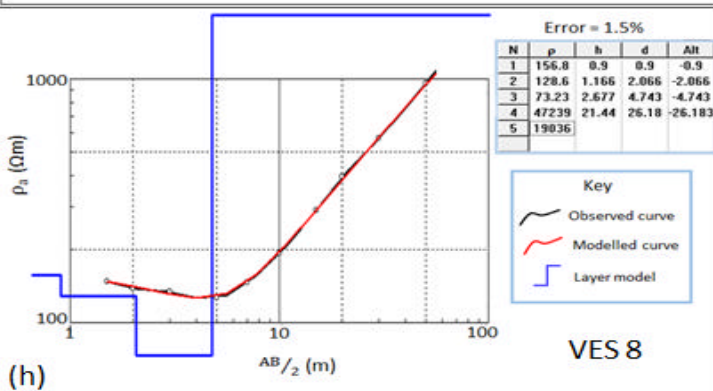

(h)

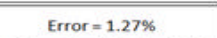

Error $=1.27 \%$
N

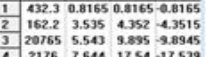
\begin{tabular}{l|lll}
2176 & 7.640 & 17.54 & -17.539 \\
\hline 5 & 930 &
\end{tabular} 93.81

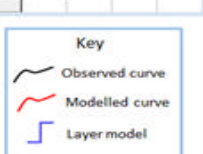

VES 9

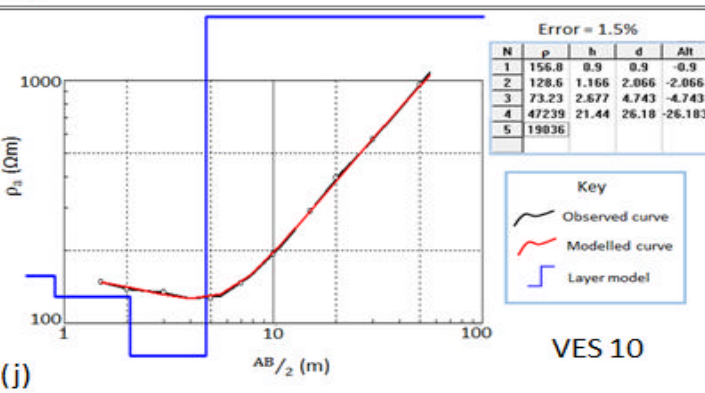

Fig. 15a-j): VES curves and geoelectric models for ten sites along National road N2 between Grahamstown and Peddie 
J. Eng. Applied Sci., 14 (6): 1885-1911, 2019

Table 2: Summary of the interpretation of VES sites 1-4 obtained along somerset East section

\begin{tabular}{|c|c|c|c|c|c|c|}
\hline Sounding site and location & No. of layers & Resistivity ( $(\mathrm{m})$ & Thickness (m) & Depth (m) & Inferred lithology & Curve type \\
\hline VES 1 & 5 & & & & & \multirow{6}{*}{$\mathrm{HKH}$} \\
\hline $25^{\circ} 41^{\prime} 42.01^{\prime \prime} \mathrm{E}$ & 1 & 176 & 0.9 & 0.9 & Top soil & \\
\hline \multirow[t]{4}{*}{$33^{\circ} 10^{\prime} 20.55^{\prime \prime} \mathrm{S}$} & 2 & 60 & 1.11 & 2.01 & Mudstone & \\
\hline & 3 & 2326 & 2.5 & 4.5 & Sandstone & \\
\hline & 4 & 291 & 17.92 & 22.41 & Consolidated shale & \\
\hline & 5 & 53057 & $\infty$ & $\infty$ & Dolerite intrusion & \\
\hline VES 2 & 5 & & & & & \\
\hline $25^{\circ} 40^{\prime} 45.10^{\prime \prime} \mathrm{E}$ & 1 & 34 & 0.64 & 0.64 & Top soil & \multirow[t]{5}{*}{ AAK } \\
\hline \multirow[t]{4}{*}{$33^{\circ} 9^{\prime} 49.89^{\prime \prime} \mathrm{S}$} & 2 & 7009 & 1.37 & 2.01 & Weathered dolerite intrusion & \\
\hline & 3 & 31601 & 8.01 & 10 & Dolerite intrusion & \\
\hline & 4 & 280000 & 8.69 & 18.7 & Dolerite intrusion & \\
\hline & 5 & 3851 & $\infty$ & $\infty$ & Sandstone & \\
\hline VES 3 & 4 & & & & & \multirow{5}{*}{$\mathrm{KH}$} \\
\hline $25^{\circ} 39^{\prime} 21.50^{\prime \prime} \mathrm{E}$ & 1 & 37 & 0.27 & 0.27 & Top soil & \\
\hline \multirow{3}{*}{$33^{\circ} 8^{\prime} 51.18^{\prime \prime} \mathrm{S}$} & 2 & 164 & 5.42 & 5.69 & Weathered sandstone & \\
\hline & 3 & 44 & 9.01 & 14.7 & Mudstone & \\
\hline & 4 & 38628 & $\infty$ & $\infty$ & Dolerite intrusion & \\
\hline VES 4 & 4 & & & & & \multirow{5}{*}{ HK } \\
\hline $25^{\circ} 37^{\prime} 51.11^{\prime \prime} \mathrm{E}$ & 1 & 301 & 1.06 & 1.06 & Top soil & \\
\hline \multirow{3}{*}{$33^{\circ} 8^{\prime} 4.17^{\prime \prime} \mathrm{S}$} & 2 & 142 & 1.53 & 2.59 & Weathered sandstone & \\
\hline & 3 & 1915 & 19 & 21.6 & Sandstone & \\
\hline & 4 & 73 & $\infty$ & $\infty$ & Consolidated shale & \\
\hline \multicolumn{7}{|c|}{ Table 3: Summary of the interpretation of VES sites 1-4 obtained along Cookhouse section } \\
\hline VES 1 & 4 & & & & & \multirow{5}{*}{$\mathrm{HA}$} \\
\hline $25^{\circ} 52^{\prime} 40.96^{\prime \prime} \mathrm{E}$ & 1 & 77 & 0.61 & 0.61 & Top soil & \\
\hline \multirow{3}{*}{$33^{\circ} 8^{\prime} 4.41^{\prime \prime} \mathrm{S}$} & 2 & 30 & 4.72 & 5.33 & Mudstone & \\
\hline & 3 & 77 & 5.64 & 11 & Weathered sandstone & \\
\hline & 4 & 1452 & $\infty$ & $\infty$ & Consolidated shale & \\
\hline VES 2 & 5 & & & & & \multirow{5}{*}{ HAA } \\
\hline $25^{\circ} 52^{\prime} 36.58^{\prime \prime} \mathrm{E}$ & 1 & 106 & 0.9 & 0.9 & Top soil & \\
\hline \multirow{4}{*}{$33^{\circ} 7^{\prime} 50.35^{\prime \prime} \mathrm{S}$} & 2 & 66 & 3.6 & 4.5 & Mudstone & \\
\hline & 3 & 149 & 5.54 & 10 & Weathered sandstone & \\
\hline & 4 & 1214 & 43.2 & 53.2 & Consolidated shale & \\
\hline & 5 & 3221 & $\infty$ & $\infty$ & Sandstone & \\
\hline VES 3 & 5 & & & & & \multirow{6}{*}{ HAA } \\
\hline $25^{\circ} 52^{\prime} 34.9^{\prime \prime} \mathrm{E}$ & 1 & 106 & 0.9 & 0.9 & Top soil & \\
\hline \multirow[t]{4}{*}{$33^{\circ} 07^{\prime} 38.7^{\prime \prime} \mathrm{S}$} & 2 & 66 & 3.4 & 4.3 & Mudstone & \\
\hline & 3 & 150 & 6.2 & 10.5 & Weathered sandstone & \\
\hline & 4 & 1218 & 44.5 & 55 & Consolidated shale & \\
\hline & 5 & 3300 & $\infty$ & $\infty$ & Sandstone & \\
\hline VES 4 & 4 & & & & & \multirow{5}{*}{ HA } \\
\hline $25^{\circ} 52^{\prime} 32.0^{\prime \prime} \mathrm{E}$ & 1 & 125 & 0.76 & 0.76 & Top soil & \\
\hline \multirow{3}{*}{$33^{\circ} 07^{\prime} 29.1^{\prime \prime S}$} & 2 & 75 & 1.37 & 2.13 & Mudstone & \\
\hline & 3 & 406 & 10.5 & 12.6 & Sandstone & \\
\hline & 4 & 1472 & $\infty$ & $\infty$ & Consolidated shale & \\
\hline
\end{tabular}

Table 4: Summary of the interpretation of VES sites 1-4 obtained along Bdford section

\begin{tabular}{|c|c|c|c|c|c|c|}
\hline Sounding site and location & No. of layers & Resistivity $(\Omega m)$ & Thickness (m) & Depth (m) & Inferred lithology & Curve type \\
\hline VES 1 & 4 & & & & & \\
\hline $26^{\circ} 21^{\prime} 42.95^{\prime \prime} \mathrm{E}$ & 1 & 126 & 0.76 & 0.76 & Top soil & \multirow[t]{4}{*}{$\mathrm{HA}$} \\
\hline \multirow{3}{*}{$33^{\circ} 11^{\prime} 53.56^{\prime \prime} \mathrm{S}$} & 2 & 74 & 1.32 & 2.08 & Mudstone & \\
\hline & 3 & 398 & 10.3 & 12.4 & Sandstone & \\
\hline & 4 & 1465 & $\infty$ & $\infty$ & Consolidated shale & \\
\hline VES 2 & 5 & & & & & \\
\hline $26^{\circ} 21^{\prime} 32.40^{\prime \prime} \mathrm{E}$ & 1 & 256 & 0.9 & 0.9 & Top soil & \multirow[t]{5}{*}{ KHA } \\
\hline \multirow{4}{*}{$33^{\circ} 11^{\prime} 46.02^{\prime \prime} \mathrm{S}$} & 2 & 1112 & 1.11 & 2.01 & Sandstone & \\
\hline & 3 & 218 & 2.48 & 4.49 & Consolidated shale & \\
\hline & 4 & 3031 & 46.6 & 51.1 & Sandstone & \\
\hline & 5 & 240000 & $\infty$ & $\infty$ & Dolerite intrusion & \\
\hline VES 3 & 4 & & & & & \\
\hline $26^{\circ} 21^{\prime} 33.91 " \mathrm{E}$ & 1 & 37 & 0.27 & 0.27 & Top soil & \multirow[t]{4}{*}{$\mathrm{KH}$} \\
\hline \multirow[t]{3}{*}{$33^{\circ} 11^{\prime} 34.36^{\prime \prime} \mathrm{S}$} & 2 & 164 & 5.42 & 5.69 & Weathered sandstone & \\
\hline & 3 & 44 & 9.01 & 14.7 & Mudstone & \\
\hline & 4 & 38628 & $\infty$ & $\infty$ & Dolerite intrusion & \\
\hline VES 4 & 5 & & & & & \multirow{6}{*}{ KHA } \\
\hline $26^{\circ} 21^{\prime} 41.23 " \mathrm{E}$ & 1 & 334 & 0.9 & 0.9 & Top soil & \\
\hline \multirow[t]{4}{*}{$33^{\circ} 11^{\prime} 26.96^{\prime \prime} \mathrm{S}$} & 2 & 485 & 1.17 & 2.07 & Weathered sandstone & \\
\hline & 3 & 93 & 2.68 & 4.75 & Mudstone & \\
\hline & 4 & 13254 & 6.15 & 10.9 & Weathered dolerite intrusion & \\
\hline & 5 & 59401 & $\infty$ & $\infty$ & Dolerite intrusion & \\
\hline
\end{tabular}


J. Eng. Applied Sci., 14 (6): 1885-1911, 2019

Table 5: Summary of the interpretation of VES sites 1-4 obtained along Adelaide section

\begin{tabular}{|c|c|c|c|c|c|c|}
\hline Sounding site and location & No. of layers & Resistivity $(\Omega m)$ & Thickness (m) & Depth (m) & Inferred lithology & Curve type \\
\hline VES 1 & 5 & & & & & \multirow{6}{*}{$\mathrm{HKH}$} \\
\hline $26^{\circ} 24^{\prime} 23.2^{\prime \prime} \mathrm{E}$ & 1 & 196 & 0.92 & 0.92 & Top soil & \\
\hline \multirow[t]{4}{*}{$33^{\circ} 12^{\prime} 04.6^{\prime \prime S} \mathrm{~S}$} & 2 & 50 & 1.09 & 2.01 & Mudstone & \\
\hline & 3 & 17797 & 8.14 & 10.2 & Dolerite intrusion & \\
\hline & 4 & 443 & 12.4 & 22.5 & Consolidated shale & \\
\hline & 5 & 461 & $\infty$ & $\infty$ & Sandstone & \\
\hline VES 2 & 5 & & & & & \multirow{6}{*}{$\mathrm{HKH}$} \\
\hline $26^{\circ} 24^{\prime} 29.4^{\prime \prime} \mathrm{E}$ & 1 & 162 & 0.92 & 0.92 & Top soil & \\
\hline \multirow[t]{4}{*}{$33^{\circ} 11^{\prime} 58.9^{\prime \prime} \mathrm{S}$} & 2 & 52 & 1.09 & 2.01 & Mudstone & \\
\hline & 3 & 17797 & 7.8 & 9.81 & Dolerite intrusion & \\
\hline & 4 & 443 & 15.3 & 25.1 & Consolidated shale & \\
\hline & 5 & 480 & $\infty$ & $\infty$ & Sandstone & \\
\hline VES 3 & 4 & & & & & \multirow{5}{*}{$\mathrm{HA}$} \\
\hline $26^{\circ} 24^{\prime} 42.64^{\prime \prime} \mathrm{E}$ & 1 & 205 & 0.9 & 0.9 & Top soil & \\
\hline \multirow[t]{3}{*}{$33^{\circ} 11^{\prime} 51.01^{\prime \prime} \mathrm{S}$} & 2 & 25 & 0.62 & 1.52 & Mudstone & \\
\hline & 3 & 4152 & 13.14 & 14.66 & Sandstone & \\
\hline & 4 & 35 & $\infty$ & $\infty$ & Mudstone & \\
\hline VES 4 & 4 & & & & & \multirow{5}{*}{$\mathrm{HK}$} \\
\hline $26^{\circ} 24^{\prime} 50.18^{\prime \prime} \mathrm{E}$ & 1 & 209 & 0.9 & 0.9 & Top soil & \\
\hline \multirow[t]{3}{*}{$33^{\circ} 11^{\prime} 43.53^{\prime \prime} \mathrm{S}$} & 2 & 25 & 0.73 & 1.63 & Mudstone & \\
\hline & 3 & 4152 & 13.1 & 14.8 & Sandstone & \\
\hline & 4 & 36 & $\infty$ & $\infty$ & Mudstone & \\
\hline
\end{tabular}

Table 6: Summary of the interpretation of VES sites 1-12 obtained along Ecca Pass section

\begin{tabular}{|c|c|c|c|c|c|c|}
\hline$\underline{\text { Sounding site and location }}$ & No. of layers & Resistivity $(\Omega \mathrm{m})$ & Thickness (m) & Depth (m) & Inferred lithology & Curve type \\
\hline VES 1 & 5 & & & & & \\
\hline $26^{\circ} 37^{\prime} 38.3^{\prime \prime} \mathrm{E}$ & 1 & 146 & 0.39 & 0.39 & Top soil & QHA \\
\hline \multirow[t]{4}{*}{$33^{\circ} 12^{\prime} 59.7^{\prime \prime S} \mathrm{~S}$} & 2 & 62 & 2.09 & 2.48 & Mudstone & \\
\hline & 3 & 26 & 2.31 & 4.79 & Consolidated shale & \\
\hline & 4 & 6493 & 6.1 & 10.9 & Weathered dolerite intrusion & \\
\hline & 5 & 30661 & $\infty$ & $\infty$ & Dolerite intrusion & \\
\hline VES 2 & 4 & & & & & \\
\hline $26^{\circ} 37^{\prime} 38.1 " \mathrm{E}$ & 1 & 139 & 0.43 & 0.43 & Top soil & $\mathrm{QH}$ \\
\hline \multirow[t]{3}{*}{$33^{\circ} 12^{\prime} 58.1^{\prime \prime} \mathrm{S}$} & 2 & 8 & 2.44 & 2.87 & Clays & \\
\hline & 3 & 1 & 2.4 & 5.27 & Clays/tuff & \\
\hline & 4 & 2079 & $\infty$ & $\infty$ & Sandstone & \\
\hline VES 3 & 5 & & & & & \\
\hline $26^{\circ} 37^{\prime} 34.0^{\prime \prime} \mathrm{E}$ & 1 & 89 & 0.9 & 0.9 & Top soil & KHA \\
\hline \multirow{4}{*}{$33^{\circ} 12 ' 55.4^{\prime \prime}$} & 2 & 611 & 1.17 & 2.07 & Sandstone & \\
\hline & 3 & 45 & 8.82 & 10.9 & Mudstone & \\
\hline & 4 & 577 & 14.1 & 25 & Consolidated shale & \\
\hline & 5 & 10618 & $\infty$ & $\infty$ & Dolerite intrusion & \\
\hline VES 4 & 5 & & & & & \\
\hline $26^{\circ} 37^{\prime} 20.2^{\prime \prime} \mathrm{E}$ & 1 & 284 & 0.9 & 0.9 & Top soil & HAK \\
\hline \multirow[t]{4}{*}{$33^{\circ} 12^{\prime} 46.8^{\prime \prime} \mathrm{S}$} & 2 & 51 & 1.17 & 2.07 & Mudstone & \\
\hline & 3 & 131 & 2.68 & 4.74 & Consolidated shale & \\
\hline & 4 & 556996 & 20.47 & 25.21 & Dolerite intrusion & \\
\hline & 5 & 139503 & $\infty$ & $\infty$ & Dolerite intrusion & \\
\hline VES 5 & 5 & & & & & \\
\hline $26^{\circ} 37^{\prime} 20.3^{\prime \prime} \mathrm{E}$ & 1 & 78 & 0.9 & 0.9 & Top soil & $\mathrm{HKH}$ \\
\hline \multirow[t]{4}{*}{$33^{\circ} 12^{\prime} 41.0^{\prime \prime} \mathrm{S}$} & 2 & 45 & 1.4 & 2.3 & Mudstone & \\
\hline & 3 & 151 & 3.57 & 5.87 & Weathered sandstone & \\
\hline & 4 & 89 & 9.13 & 15 & Mudstone & \\
\hline & 5 & 852 & $\infty$ & $\infty$ & Consolidated shale & \\
\hline VES 6 & 5 & & & & & \\
\hline $26^{\circ} 37^{\prime} 21.4^{\prime \prime} \mathrm{E}$ & 1 & 400 & 0.84 & 0.84 & Top soil & HAK \\
\hline \multirow{4}{*}{$33^{\circ} 12^{\prime} 38.3^{\prime \prime} \mathrm{S}$} & 2 & 274 & 1.01 & 1.85 & Consolidated shale & \\
\hline & 3 & 356 & 2.82 & 4.67 & Sandstone & \\
\hline & 4 & 1438 & 4.98 & 9.65 & Consolidated shale & \\
\hline & 5 & 1322 & $\infty$ & $\infty$ & Sandstone & \\
\hline VES 7 & 5 & & & & & \\
\hline $26^{\circ} 37^{\prime} 19.8^{\prime \prime} \mathrm{E}$ & 1 & 92 & 1.05 & 1.05 & Top soil & HAA \\
\hline \multirow[t]{4}{*}{$33^{\circ} 12^{\prime} 37.1^{\prime \prime S}$} & 2 & 17 & 0.98 & 2.03 & Clays & \\
\hline & 3 & 340 & 0.39 & 2.42 & Sandstone & \\
\hline & 4 & 29164 & 12.6 & 15 & Dolerite intrusion & \\
\hline & 5 & 29165 & $\infty$ & $\infty$ & Dolerite intrusion & \\
\hline VE 8 & 4 & & & & & \\
\hline $26^{\circ} 37^{\prime} 20.0^{\prime \prime} \mathrm{E}$ & 1 & 153 & 1.7 & 1.7 & Top soil & $\mathrm{HA}$ \\
\hline \multirow[t]{2}{*}{$33^{\circ} 12 ' 28.1^{\prime \prime S} \mathrm{~S}$} & 2 & 30 & 1.33 & 3.03 & Mudstone & \\
\hline & 3 & 175 & 15.33 & 18.36 & Sandstone & \\
\hline
\end{tabular}


J. Eng. Applied Sci., 14 (6): 1885-1911, 2019

\begin{tabular}{|c|c|c|c|c|c|c|}
\hline Sounding site and location & No. of layers & Resistivity ( $(\mathrm{m})$ & Thickness (m) & Depth (m) & Inferred lithology & Curve type \\
\hline & 4 & 131020 & $\infty$ & $\infty$ & Dolerite intrusion & \\
\hline VES 9 & 5 & & & & & \\
\hline $26^{\circ} 37^{\prime} 15.1 " \mathrm{E}$ & 1 & 142 & 0.9 & 0.9 & Top soil & HAA \\
\hline \multirow[t]{4}{*}{$33^{\circ} 12^{\prime} 14.8^{\prime \prime} \mathrm{S}$} & 2 & 55 & 1.11 & 2.01 & Mudstone & \\
\hline & 3 & 9189 & 2.48 & 4.49 & Weathered dolerite intrusion & \\
\hline & 4 & 120000 & 18.2 & 22.7 & Dolerite intrusion & \\
\hline & 5 & 220000 & $\infty$ & $\infty$ & Dolerite intrusion & \\
\hline VES 10 & 5 & & & & & \\
\hline $26^{\circ} 37^{\prime} 02.6^{\prime \prime} \mathrm{E}$ & 1 & 321 & 2.19 & 2.19 & Top soil & HAK \\
\hline \multirow[t]{4}{*}{$33^{\circ} 11^{\prime} 43.6^{\prime \prime} \mathrm{S}$} & 2 & 72 & 2.99 & 5.17 & Mudstone & \\
\hline & 3 & 320 & 2.89 & 8.06 & Consolidated shale & \\
\hline & 4 & 4912 & 11.6 & 19.66 & Sandstone & \\
\hline & 5 & 25 & $\infty$ & $\infty$ & Mudstone & \\
\hline VES 11 & 4 & & & & & \\
\hline $26^{\circ} 36^{\prime} 43.8^{\prime \prime} \mathrm{E}$ & 1 & 153 & 1.7 & 1.7 & Top soil & $\mathrm{HA}$ \\
\hline \multirow[t]{3}{*}{$33^{\circ} 11^{\prime} 03.8^{\prime \prime} \mathrm{S}$} & 2 & 30 & 1.33 & 3.03 & Mudstone & \\
\hline & 3 & 174 & 15.33 & 18.36 & Sandstone & \\
\hline & 4 & 131020 & $\infty$ & $\infty$ & Dolerite intrusion & \\
\hline VES 12 & 5 & & & & & \\
\hline $26^{\circ} 36^{\prime} 46.4^{\prime \prime} \mathrm{E}$ & 1 & 343 & 0.46 & 0.46 & Top soil & HKQ \\
\hline \multirow[t]{4}{*}{$33^{\circ} 10^{\prime} 55.7^{\prime \prime} \mathrm{S}$} & 2 & 47 & 1.08 & 1.54 & Mudstone & \\
\hline & 3 & 5894 & 2.57 & 4.12 & Weathered dolerite intrusion & \\
\hline & 4 & 198 & 3.08 & 7.2 & Consolidated shale & \\
\hline & 5 & 3 & $\infty$ & $\infty$ & Clays & \\
\hline $\begin{array}{l}\text { Table 7: Summary of the in } \\
\text { Sounding site and location }\end{array}$ & $\begin{array}{l}\text { oretation of VE: } \\
\text { No. of layers }\end{array}$ & $\begin{array}{l}\text { sites } 1-10 \text { obtained } \\
\text { Resistivity }(\Omega m)\end{array}$ & $\begin{array}{l}\text { g Peddie section } \\
\text { Thickness (m) }\end{array}$ & Depth (m) & Inferred lithology & Curve type \\
\hline VES 1 & 5 & 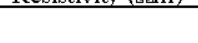 & & Depui (i11) & H & \\
\hline $26^{\circ} 55^{\prime} 48.0^{\prime \prime} \mathrm{E}$ & 1 & 844 & 0.99 & 0.99 & Top soil & QHA \\
\hline \multirow[t]{4}{*}{$33^{\circ} 15^{\prime} 45.2^{\prime \prime} \mathrm{S}$} & 2 & 182 & 0.66 & 1.65 & Weathered sandstone & \\
\hline & 3 & 97 & 2.83 & 4.48 & Mudstone & \\
\hline & 4 & 14819 & 6.41 & 10.89 & Weathered dolerite intrusion & \\
\hline & 5 & 96198 & $\infty$ & $\infty$ & Dolerite intrusion & \\
\hline VES 2 & 5 & & & & & \\
\hline $26^{\circ} 55^{\prime} 49.6^{\prime \prime} \mathrm{E}$ & 1 & 469 & 0.9 & 0.9 & Top soil & KHA \\
\hline \multirow{4}{*}{$33^{\circ} 15^{\prime} 42.9^{\prime \prime} \mathrm{S}$} & 2 & 551 & 1.4 & 2.3 & Consolidated shale & \\
\hline & 3 & 254 & 3.57 & 5.87 & Sandstone & \\
\hline & 4 & 317 & 9.13 & 15 & Consolidated shale & \\
\hline & 5 & 1334 & $\infty$ & $\infty$ & Sandstone & \\
\hline VES 3 & 5 & & & & & \\
\hline $26^{\circ} 55^{\prime} 51.4^{\prime \prime} \mathrm{E}$ & 1 & 182 & 0.9 & 0.9 & Top soil & HAA \\
\hline \multirow[t]{4}{*}{$33^{\circ} 15^{\prime} 41.5^{\prime \prime} \mathrm{S}$} & 2 & 87 & 1.4 & 2.3 & Mudstone & \\
\hline & 3 & 157 & 3.57 & 5.87 & Weathered sandstone & \\
\hline & 4 & 30440 & 9.13 & 15 & Dolerite intrusion & \\
\hline & 5 & 38102 & $\infty$ & $\infty$ & Dolerite intrusion & \\
\hline VES 4 & 5 & & & & & \\
\hline $26^{\circ} 55^{\prime} 53.0^{\prime \prime} \mathrm{E}$ & 1 & 107 & 0.9 & 0.9 & Top soil & HAA \\
\hline \multirow[t]{4}{*}{$33^{\circ} 15^{\prime} 40.3^{\prime \prime} \mathrm{S}$} & 2 & 35 & 1.4 & 2.3 & Mudstone & \\
\hline & 3 & 752 & 3.57 & 5.87 & Consolidated shale & \\
\hline & 4 & 1399 & 9.13 & 15 & Sandstone & \\
\hline & 5 & 12499 & $\infty$ & $\infty$ & Weathered dolerite intrusion & \\
\hline VES 5 & 5 & & & & & \\
\hline $26^{\circ} 56^{\prime} 02.0^{\prime \prime} \mathrm{E}$ & 1 & 334 & 0.9 & 0.9 & Top soil & KHA \\
\hline \multirow{4}{*}{$33^{\circ} 15^{\prime} 32.5^{\prime \prime} \mathrm{s}$} & 2 & 485 & 1.17 & 2.07 & Sandstone & \\
\hline & 3 & 93 & 2.68 & 4.75 & Mudstone & \\
\hline & 4 & 13254 & 6.15 & 10.9 & Weathered dolerite intrusion & \\
\hline & 5 & 59401 & $\infty$ & $\infty$ & Dolerite intrusion & \\
\hline VES 6 & 4 & & & & & \\
\hline $26^{\circ} 56^{\prime} 03.6^{\prime \prime} \mathrm{E}$ & 1 & 433 & 0.78 & 0.78 & Top soil & $\mathrm{QH}$ \\
\hline \multirow[t]{3}{*}{$33^{\circ} 15^{\prime} 30.6^{\prime \prime S}$} & 2 & 217 & 2.01 & 2.8 & Sandstone & \\
\hline & 3 & 139 & 4.2 & 6.99 & Consolidated shale & \\
\hline & 4 & 8393 & $\infty$ & $\infty$ & Weathered dolerite intrusion & \\
\hline VES 7 & 4 & & & & & \\
\hline $26^{\circ} 56^{\prime} 05.4^{\prime \prime} \mathrm{E}$ & 1 & 301 & 1.06 & 1.06 & Top soil & $\mathrm{HK}$ \\
\hline \multirow[t]{3}{*}{$33^{\circ} 15^{\prime} 29.3^{\prime \prime S}$} & 2 & 140 & 1.46 & 2.52 & Consolidated shale & \\
\hline & 3 & 1915 & 15.21 & 17.73 & Sandstone & \\
\hline & 4 & 73 & $\infty$ & $\infty$ & Weathered sandstone & \\
\hline VE 8 & 5 & & & & & \\
\hline $26^{\circ} 56^{\prime} 17.4^{\prime \prime} \mathrm{E}$ & 1 & 492 & 0.69 & 0.69 & Top soil & HAK \\
\hline $33^{\circ} 15^{\prime} 27.7^{\prime \prime}$ & 2 & 92 & 1.13 & 1.82 & Weathered sandstone & \\
\hline
\end{tabular}




\begin{tabular}{|c|c|c|c|c|c|c|}
\hline Sounding site and location & No. of layers & Resistivity $(\Omega m)$ & Thickness (m) & Depth (m) & Inferred lithology & Curve type \\
\hline & 3 & 19457 & 2.92 & 4.74 & Weathered dolerite intrusion & \\
\hline & 4 & 86890 & 20.26 & 25 & Dolerite intrusion & \\
\hline & 5 & 41099 & & & Dolerite intrusion & \\
\hline VES 9 & 5 & & & & & \\
\hline $26^{\circ} 56^{\prime} 33.9^{\prime \prime} \mathrm{E}$ & 1 & 432 & 0.82 & 0.82 & Top soil & HKQ \\
\hline \multirow[t]{4}{*}{$33^{\circ} 15^{\prime} 26.4^{\prime \prime} \mathrm{S}$} & 2 & 162 & 3.54 & 4.35 & Weathered sandstone & \\
\hline & 3 & 20765 & 5.54 & 9.9 & Dolerite intrusion & \\
\hline & 4 & 2176 & 7.64 & 17.54 & Sandstone & \\
\hline & 5 & 94 & & & Consolidated shale & \\
\hline VES 10 & 5 & & & & & \\
\hline $26^{\circ} 59^{\prime} 58.0^{\prime \prime} \mathrm{E}$ & 1 & 157 & 0.9 & 0.9 & Top soil & QHK \\
\hline \multirow{4}{*}{$33^{\circ} 14^{\prime} 16.8^{\prime \prime} \mathrm{S}$} & 2 & 129 & 1.17 & 2.07 & Weathered sandstone & \\
\hline & 3 & 73 & 2.68 & 4.74 & Mudstone & \\
\hline & 4 & 47239 & 21.44 & 26.18 & Dolerite intrusion & \\
\hline & 5 & 19036 & & & Dolerite intrusion & \\
\hline
\end{tabular}

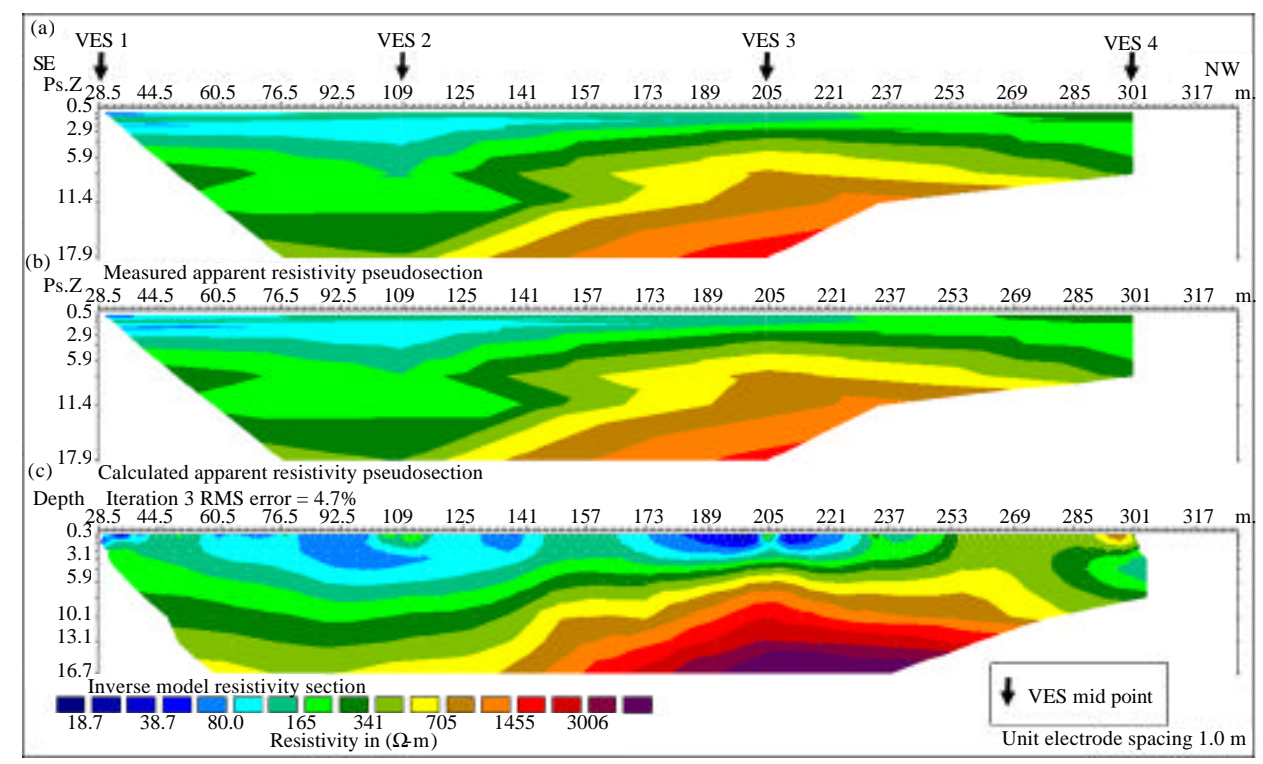

Fig. 16: Pseudosection of the measured and calculated apparent resistivity data using a Schlumberger array on road-cut exposures of the Ecca Group along Regional road R335 between Somerset East and Kirkwood

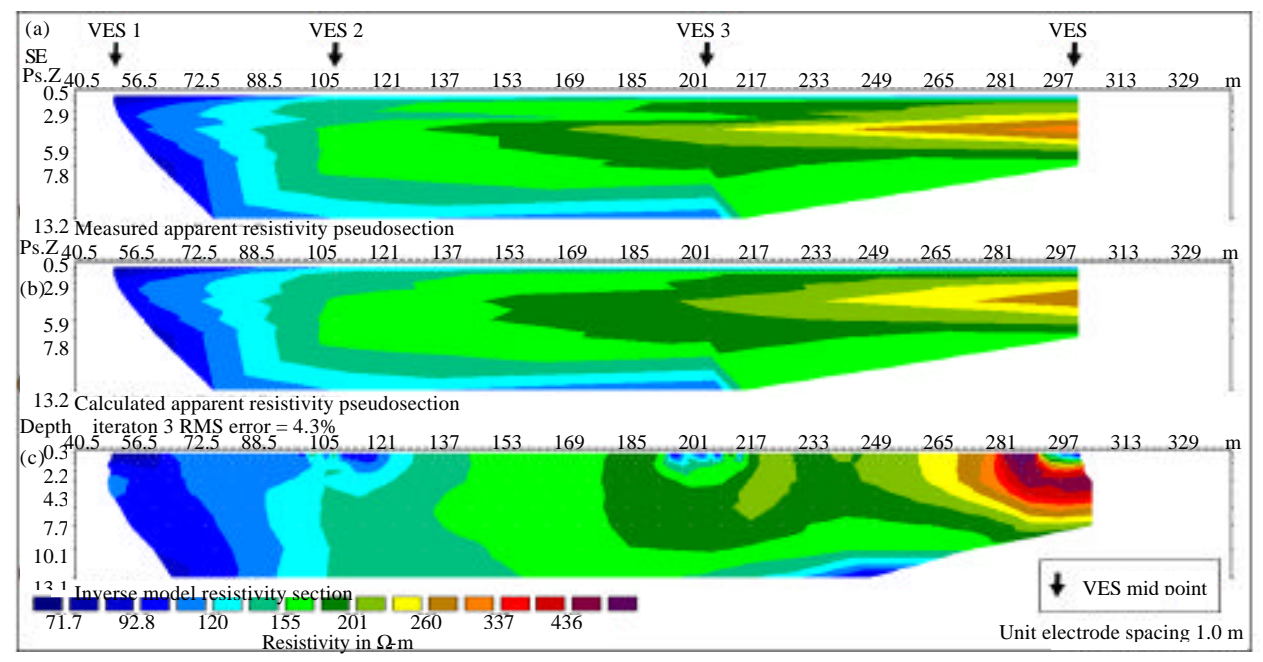

Fig. 17: Pseudosection of the measured and calculated apparent resistivity data using a Schlumberger array on road-cut exposures of the Ecca Group along National road N10 between Paterson and Cookhouse 
$\Omega \mathrm{m}$ and 2.31-19 $\mathrm{m}$, respectively. In most of the VES points, based on the resistivity value this layer is inferred to be sandstone and is weathered in some places, especially, along National road N10 to Cookhouse. However, in some of the VES points this layer is also inferred to be dolerite intrusion, mudstone, consolidated shale and clay/tuff. The 4th and 5 th layers have resistivity values ranging from 35-556996 and 3-240000 $\Omega \mathrm{m}$, respectively. The thickness of the fifth layer is not defined, since, it is the last layer. Based on the resistivity values, the inferred lithologies for these layers vary from consolidated shale, dolerite intrusion, mudstone and sandstone (Table 2-7). The curves are predominantly combination of $\mathrm{HA}, \mathrm{HK}, \mathrm{KH}, \mathrm{QH}, \mathrm{AAK}, \mathrm{HAA}$, HAK, HKH, HKQ, KHA and QHA curve-types indicating the presence of four and five layer subsurface layers.

Apparent resistivity pseudosections: Apparent resistivity pseudosections were created by combining resistivity sounding data for several sites along the same line (Fig. 16-21). The VES sites are not exactly co-linear and as such it was assumed that there is no change in geology over a small area. The inverse model (Fig. 16c) of the data obtained along Regional road R335 to Somerset East shows a general increase in apparent resistivity with depth. The 2-D resistivity structure delineated a low resistive top layer with resistivity values of $<20 \Omega \mathrm{m}$, typical of clays (top soil). This is followed by a layer of resistivity values varying between 20 and $150 \Omega \mathrm{m}$ and is inferred to have a composition (resistivity values) similar to mudstone and siltstone. The 3rd layer has resistivity values varying between 150 and $200 \Omega \mathrm{m}$ and is interpreted to be weathered sandstones. The resistivity of the 4 th layer varies from $200-2000 \Omega \mathrm{m}$. This layer is inferred to be consolidated shale as shown in Table 2. At a depth of about $12 \mathrm{~m}$ and distance between 157 and $269 \mathrm{~m}$ (Fig. 16c), a more resistive body tends to compress the overlying sedimentary units as it attempts to get to the surface. This resistive body with apparent resistivity of $>2500 \Omega \mathrm{m}$ is inferred to be dolerite intrusion.

The pseudosection shown in Fig. 17 is generated from data obtained on road-cut exposure of the Ecca Group along national road N10 to cookhouse. Up to a depth of about $13 \mathrm{~m}$, the sediments in the area are characterized by low apparent resistivities, varying between 30 and $3300 \Omega \mathrm{m}$ (Fig. 17c). The apparent resistivity generally decreases in N-S direction along the section or profile. Between the depth of about 2 and $5 \mathrm{~m}$ and distance of about 280 and $305 \mathrm{~m}$ (Fig. 17c), a more resistive body ( $>340 \Omega \mathrm{m}$; reddish colour) underlies a pocket of less resistive unit and also outcrop to the surface between the distance of 281 and $289 \mathrm{~m}$. This resistive body with apparent resistivity between 1200 and $3300 \Omega \mathrm{m}$ is inferred to be either consolidated shale or sandstone. Figure 18 and 19 show the 2-D resistivity

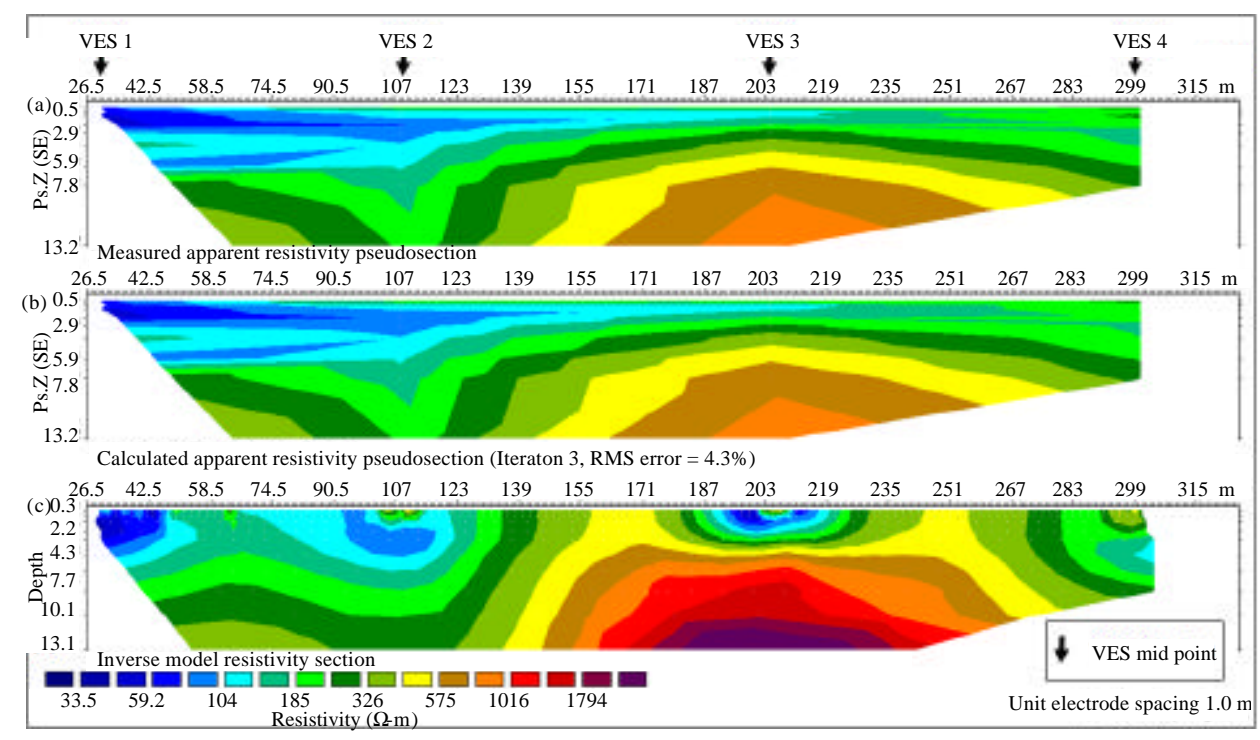

Fig. 18: Pseudosection of the measured and calculated apparent resistivity data using a Schlumberger array on road-cut exposures of the Ecca Group along Regional road R350 between Grahamstown and Bedford 
J. Eng. Applied Sci., 14 (6): 1885-1911, 2019

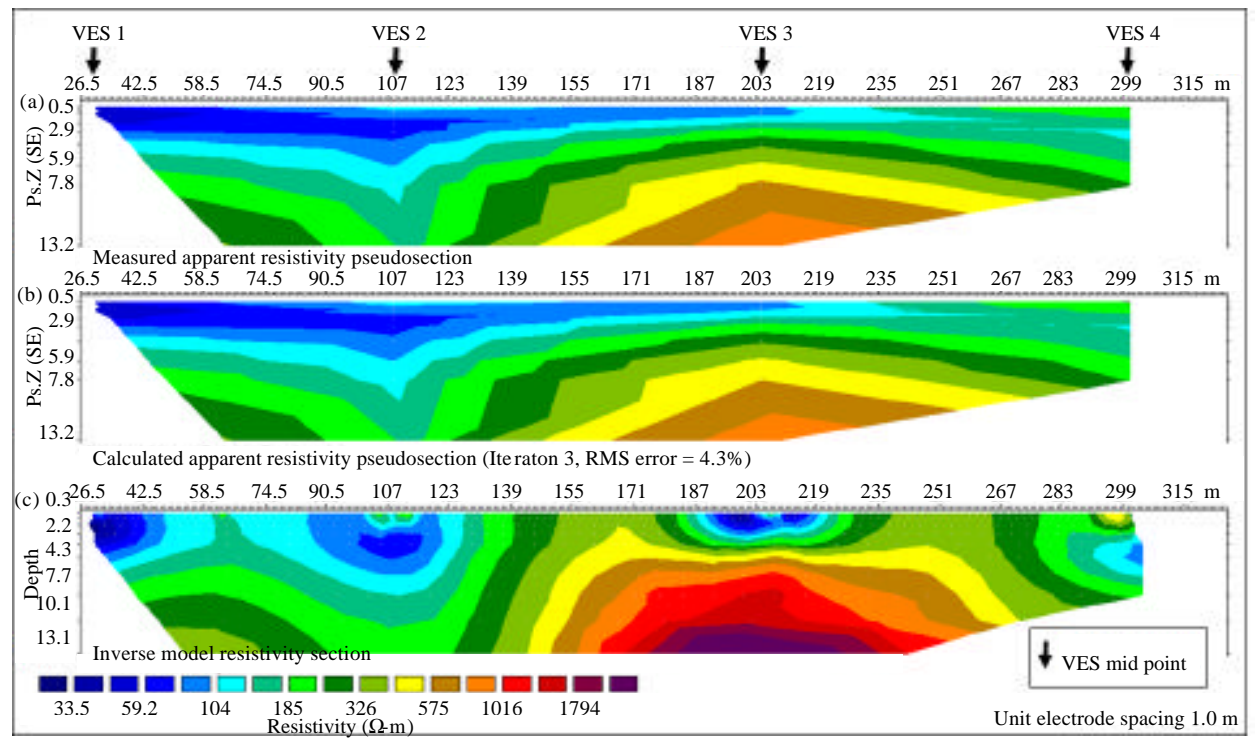

Fig. 19: Pseudosection of the measured and calculated apparent resistivity data using a Schlumberger array on road-cut exposures of the Ecca Group along Regional road R344 between Grahamstown and Adelaide

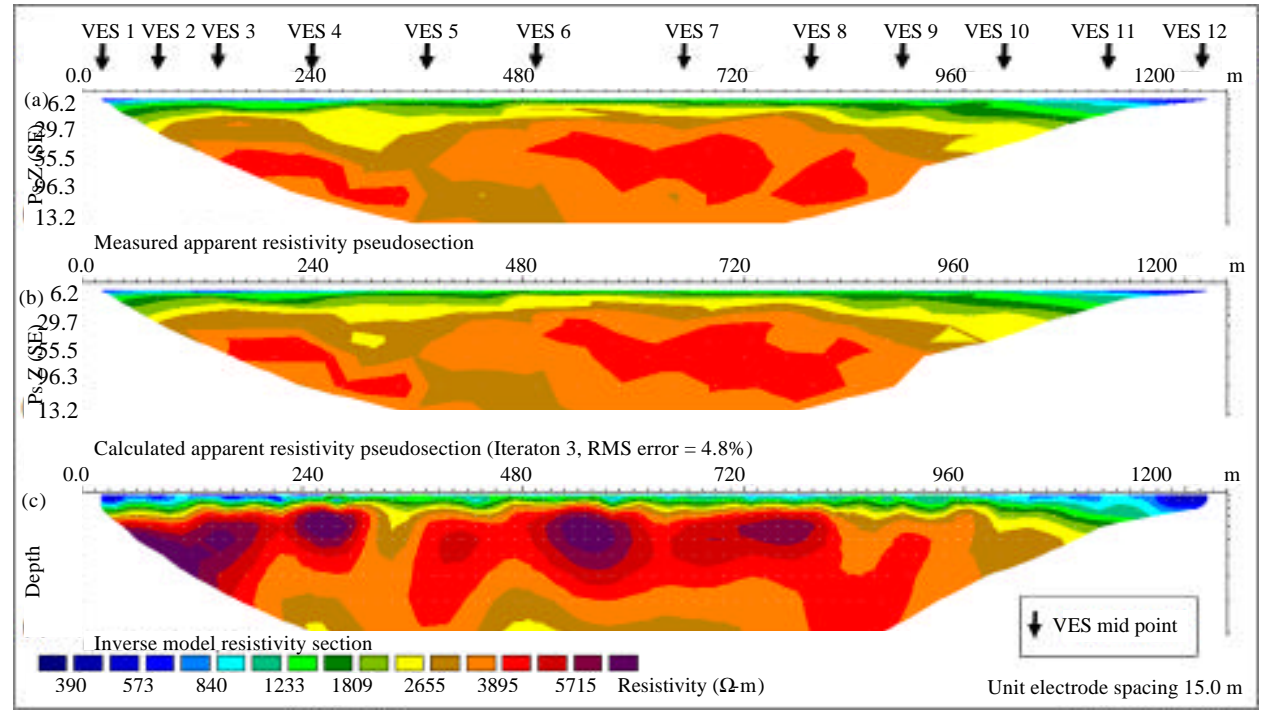

Fig. 20: Pseudosection of the measured and calculated apparent resistivity data using a Schlumberger array on road-cut exposures of the Ecca Group along Regional road R67 between Grahamstown and Fort Beaufort (Ecca Pass)

structures along Regional roads R350 to Bedford and R344 to Adelaide. The inverse models for these sections in Fig. $18 \mathrm{c}$ and $19 \mathrm{c}$ show a similar pattern or trend with Fig. 16, thus, they are not described to avoid repetition. The only noticeable difference in the model is that in Fig. $18 \mathrm{c}$, the inferred 3rd layer of resistivity values of $400-575$ $\Omega \mathrm{m}$ is exposed to the surface whereas in Fig. $16 \mathrm{c}$ and $19 \mathrm{c}$, the layer is buried at shallow depth below the surface. The inverse model in Fig. 20c is characterized by low and high resistivities with high resistivities $(>3500 \Omega \mathrm{m}$ ) predominating. The low resistive units with resistivity varying from about 1-2000 $\Omega \mathrm{m}$ occurred from the surface down to a depth of approximately $20 \mathrm{~m}$. These units correspond to the Ecca Group rocks and based on their resistivity values they are inferred to be top soil (clays), mudstones and consolidated shale. Areas with apparent resistivity values between 2000 and $5000 \Omega \mathrm{m}$ are thought to be sandstones. On the other hand, the more resistive 


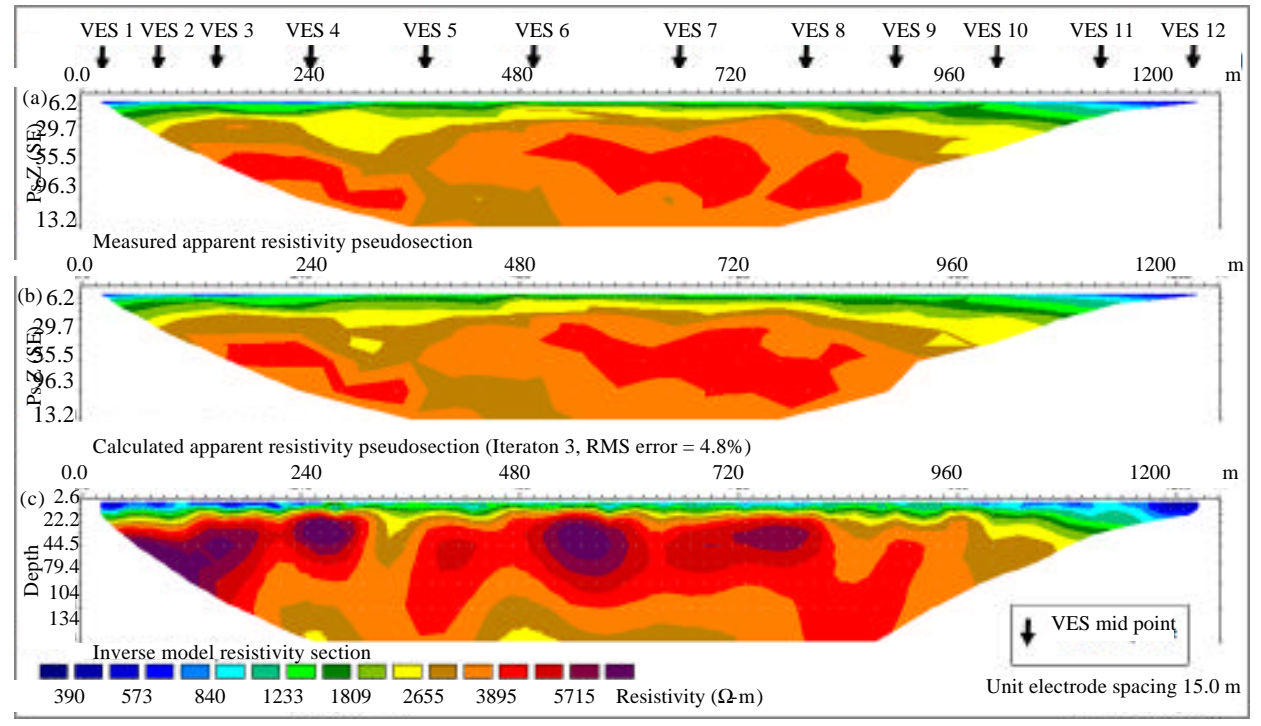

Fig. 21: Pseudosection of the measured and calculated apparent resistivity data using a Schlumberger array on road-cut exposures of the Ecca Group along National road N2 between Grahamstown and Peddie

unit (s) occurring at depth of about $20 \mathrm{~m}$ up to $104 \mathrm{~m}$ and having resistivity values of $>5000 \Omega \mathrm{m}$ is inferred to be dolerite intrusions. The inverse model (Fig. 21c) of the data set obtained along national road N2 to Peddie shows two low resistivity anomalies on either ends of the line $(<840 \Omega \mathrm{m})$. The anomalies have been interpreted as top soil. Furthermore, Fig. 21c also indicate high resistivity values $(>4000 \Omega \mathrm{m})$ and this layer is inferred to be dolerite intrusions occurring at depth of about 16 up to $79 \mathrm{~m}$ below the surface.

In the study area, the magnetic map revealed three main magnetic zones or anomalies and these three magnetic high zones are due to magnetic sources at depth (Fig.3). The magnetic map shows some circular (in form of a ring) structures and lineaments which coincides with the dolerites that were shown on the geological map. In addition, some new dolerite intrusions are revealed by the magnetic map. Chevallier et al. (2001) documented that the preferential erosion of the trapped sediments within the structure, usually accentuate the rims of the ring topographically. Thus, resulting in the overall appearance of a ring-like structure observed in the magnetic map and first described around Queenstown by Du Toit (1920). Based on the power spectrum result, the approximated depth to the upper part (top) of the shallow and deep seated magnetic sources are 700 and $15000 \mathrm{~m}$, respectively. Depth slicing revealed that the intrusions (dolerites) are pervasive in the area, extending down to a depth of about $5400 \mathrm{~m}$. Thereafter, the magnetic signatures from the dolerite intrusions become weaker and eventually disappear at a depth of about $16000 \mathrm{~m}$. This possibly indicates that the Karoo intrusions were emplaced near the surface, existing at the targeted depth for shale gas exploration. Knowledge of the geometry and depth to the dolerite intrusions is very crucial to successful exploration of the Karoo shale gas. However, one cannot totally depend or rely on information from depth slicing alone. The BMA is seen or present in depth slices 1-4 and it becomes stronger and more visible with depth, perhaps indicating that the sources is deep. The BMA runs NE-SW of the study area and it is inferred to be confined to the basement that underlies the Karoo Basin. The source or sources of the BMA is very deep as revealed by the models, perhaps located within the underlying basement. This findings or assumption agrees with the work of Pitts et al. (1992) and Weckmann et al. (2007a, b). Based on the depth slicing results, the anomaly that has the shape of bean (refer to as "bean shape anomaly") acts in a way that is comparable to the BMA. Hence, the bean shape anomaly may have sources located within the same depth range with the sources of the BMA.

The Bouguer gravity anomaly map depicted in Fig. 6 shows gravity values increasing from around $141 \mathrm{mGal}$ near Graaff-Reinet and Somerset East (inland) to approximately $60 \mathrm{mGal}$ far South of peddie, Butterworth and Humansdorp (coastal areas). The low gravity values inland are of short wavelength and probably resulting 
from shallow source bodies, maybe the Karoo dolerite intrusions. Alternatively, the gravity highs, mostly along the coast give indications that the dominant gravity variation is of long wavelength, perhaps suggesting that their source causative body is located very deep below the surface (probably the Moho). These findings are consistent with the works of Svensen et al. (2007) about the causative bodies of gravity anomalies that occur on the South-Eastern Karoo Basin. Based on the gravity models it can be inferred that the long wavelength variation in gravity is possibly due to deep source(s) like the Moho that shallows upward towards the coastline (Fig. 7). As observed in the model, the Moho is horizontal at a depth of approximately $45 \mathrm{~km}$ inland and thereafter shallows or slightly tilts upward to a depth of around 42 $\mathrm{km}$ in coastal areas. The obtained Moho depths falls within the depth range of $42-45 \mathrm{~km}$ documented by Tedla et al. (2011), Stankiewicz and de Wit (2013) for inland sections. In addition, the models show a total thickness (highest) of about $8 \mathrm{~km}$ for the formations that make up the Karoo Supergroup.

The targeted Karoo formation for onshore petroleum exploration is the Ecca Group and the targeted exploration depth range from $3-5 \mathrm{~km}$. As revealed by the models, the modelled dolerite intrusions extends to a depth of about $5400 \mathrm{~m}$ and form a network of interconnected sills, dykes and inclined sheets, resulting in a complex structure of the Main Karoo Basin. These findings are consistent with the works of Chevallier and Woodford (1999) and they proposed that the dolerite dykes feed into the inclined sheets then propagate into an external sill and finally into an internal sill. Furthermore, these dolerites that outcrop in the area are interconnected or intersected at depth as revealed in the gravity models. The dolerite intrusions could have affected the quality of the petroleum resources and again poses more danger to fracturing (fracking) the Karoo for petroleum resources, especially, shale gas. The illustration of dolerite intrusions shown by the models is similar to the models documented by Chevallier et al. (2001) which show a network of dolerite intrusions in the subsurface slicing through the Karoo sediments. Enslin and Stiphanic (2015) documented that with good knowledge of the distribution and geometry of the Karoo dolerites, the next step for companies exploring the Karoo for shale gas is to drill several deep wells to intersect the carbonaceous shale in dolerite free and dolerite prominent areas. This will help to better understand changes in shale rock properties (i.e., depth, thickness, organic carbon content, porosity and mineralogy) and the effects of dolerites on the shales maturity.
The carbonaceous shales of the lower Ecca Group formations are thought to be a good source and reservoir rocks for petroleum exploration in South Africa. In the study area, VES 1 in (Fig. 16-19) and VES 1 and 2 in Fig. 20 and 21 were carried out on exposure of the lower Ecca Group formations these areas are characterised by low resistivity values compared to other areas along the same section. However, in Fig. 16 and 17, the area between the distance of 180 and $220 \mathrm{~m}$ in the Ripon and Fort Brown Formations (upper Ecca Group) have lower resistivity values than the lower Ecca Group formations. These areas outcrop to the surface along some sections and correspond to the carbonaceous shale of the Ripon Formation. Different factors have been used to explain the low resistivity or high conductivity of the Ecca shales; these include increased pyrite content (Duba et al. 1994), enrichment in graphite (Pous et al. 2004) and enrichment in organic matter (Branch et al., 2007). Nevertheless it is important to note that in the Main Karoo Basin, the Whitehill formation is an extensive geophysical (magnetotelluric) marker that is potentially important for shale gas exploration (Weckmann et al. 2007a, b). With the exception of the Cookhouse section, all the measured sections have been intruded by dolerites. The apparent lack of dolerites in the area could led one to suggest that this part of the basin would be the best place to carry out shale gas exploration, as the Ecca Group formations have been least affected by dolerites. However, more research like collecting high resolution aeromagnetic and seismic data would aid better mapping of the geometry of dolerites closer to the shale reservoir. The effect of the network of dolerite intrusions on sounding curves depends on its form, dimensions, density of intrusions within it and their mode of occurrence. The general forms of these dolerite intrusions are sills, inclined sheets and dykes within a matrix of sediments. Due to the hardness and high resistivity of dolerite intrusions they are likely to introduce a technical difficulty in the drilling stage of the hydraulic fracturing process which will in turn reduce the recovery factor and lower the tecnically recoverable sources.

Generally, dolerite intrusions (mostly sills) are impermeable and act as barriers for fluid migration. As documented in Baiyegunhi (2015), the lower Ecca Group is organically enriched with TOC of the Prince Albert, Whitehill and Collingham Formations reaching up to 6.35, 7.3 and 0.93 wt.\%, respectively. During the intrusion of dolerites, temperatures at the contact (contact metamorphism) may have likely exceeded $1000^{\circ} \mathrm{C}$, resulting in thermal cracking of organic matter and 
devolatization of water bearing minerals (Aarnes et al., 2010). The extent to which these dolerites (i.e., dykes) thermally cracked the lower Ecca shales will be important in the quantification of the natural gas that remains in the carbonaceous shale. Observations from borehole studies by Svensen et al. (2007), Aarnes et al. (2011) and Baiyegunhi (2015) revealed that carbonaceous shales of the lower Ecca Group at contact with dolerites appeared to be pale grey rather than the characteristic dark grey to black colour. In addition, the organic geochemistry results documented by Baiyegunhi (2015) showed that the Ecca shales have lower TOC (wt. \%) content in areas that are intruded by dolerites or close to dolerite intrusions. Several researchers (Rowsell and De Swardt, 1976; Svensen et al., 2007; Aarnes et al., 2011) have documented that rapid heating from multiple dolerite intrusions could be directly related to the sharp decrease in organic carbon content and increase in vitrinite reflectance in the host rocks of the lower Ecca Group.

\section{CONCLUSION}

This study have shown the efficacy of integrated geophysical studies and how existing aeromagnetic and gravity data over the South-Eastern Karoo Basin allow for a more continuous picture of the geometry of dolerites within the main Karoo Basin. The targeted depth for unconventional shale gas exploration in the basin falls between $3000-5000 \mathrm{~m}$ the ground surface. As observed on the magnetic map, the magnetic signatures from the dolerite intrusions become broader up to the depth of $5400 \mathrm{~m}$ and eventually disappear at a depth of about 15600 $\mathrm{m}$. This possibly indicates that the Karoo intrusions were emplaced near the surface, existing at the targeted depth for shale gas exploration. The Bouguer anomaly map give indications that the dominant gravity variation is of long wavelength, thus, it could be as a result of deep source(s) like the Moho that shallows southward towards the coast. Based on the gravity models and magnetic depth slices it can be inferred that the mapped intrusions (dolerites) are interconnected at depth, extending from the surface down to a depth of approximately $5400 \mathrm{~m}$. The subsurface apparent resistivity of the Ecca Group varies between 2 and $557000 \Omega \mathrm{m}$. The pseudosections exhibit gradational change in resistivity with depth, indicating the different rock units. Also, the pseudosections revealed that the lower Ecca Group is generally characterised by low resistivity values compared to the upper Ecca Group. These low resistivities are thought to be as a result of high organic matter and pyrite contents in the lower Ecca shales. Generally, the geophysical results have revealed the basin architecture and extensive network of dolerite intrusions throughout the study area which has drawn attention to fracking operations. With the exception of the cookhouse section, all the measured sections have been intruded by dolerites. Due to the hardness and high resistivity of the dolerite intrusions they are likely to introduce a technical difficulty in the drilling stage of the hydraulic fracturing process which will in turn reduce the recovery factor. Indeed, the datasets used in this study provide a foundation on which new knowledge can be built.

\section{ACKNOWLEDGEMENTS}

The researchers would like to thank the Centre of Excellence for Integrated Mineral and Energy Resource Analysis (CIMERA) and the Govan Mbeki Research and Development Centre (GMRDC) at Fort Hare University for financial support. The researchers declare that there is no conflict of interest regarding the publishing of this research work.

\section{REFERENCES}

Aarnes, I., H. Svensen, J.A. Connolly and Y.Y. Podladchikov, 2010. How contact metamorphism can trigger global climate changes: Modeling gas generation around igneous sills in sedimentary basins. Cosmochim. Acta, 74: 7179-7195.

Aarnes, I., H. Svensen, S. Polteau and S. Planke, 2011. Contact metamorphic devolatilization of shale's in the Karoo Basin, South Africa and the effects of multiple sill intrusions. Chem. Geol., 281: 181-194.

Baiyegunhi, C. and O. Gwavava, 2016. Variations in Isochore thickness of the Ecca sediments in the Eastern cape province of South Africa, as Deduced from gravity models. Acta Geol. Sin. English Ed., 90: 1699-1712.

Baiyegunhi, C. and O. Gwavava, 2017. Magnetic investigation and $2 \frac{1}{2} \mathrm{D}$ gravity profile modelling across the Beattie magnetic anomaly in the Southeastern Karoo Basin, South Africa. Acta Geophys., 65: 119-138.

Baiyegunhi, C., 2015. Geological and geophysical investigation of the Southeastern Karoo Basin, South Africa. MSc Thesis, University of Fort Hare, Alice, South Africa.

Branch, T., O. Ritter, U. Weckmann, R.F. Sachsenhofer and F. Schilling, 2007. The whitehill formation-a high conductivity marker horizon in the Karoo Basin. South African J. Geol., 110: 465-476.

Catuneanu, O., 2004. Retroarc foreland systems-evolution through time. J. Afr. Earth Sci., 38: 225-242.

Catuneanu, O., H. Wopfner, P.G. Eriksson, B. Cairncross and B.S. Rubidge et al., 2005. The Karoo basins of South-central Africa. J. Afr. Earth Sci., 43: 211-253. 
Catuneanu, O., P.J. Hancox and B.S. Rubidge, 1998. Reciprocal flexural behaviour and contrasting stratigraphies: A new basin development model for the Karoo retroarc foreland system, South Africa. Basin Res., 10: 417-439.

Catuneanu, O., P.J. Hancox, B. Cairncross and B.S. Rubidge, 2002. Foredeep submarine fans and forebulge deltas: Orogenic off-loading in the underfilled Karoo Basin. J. Afr. Earth Sci., 35: 489-502.

Chevallier, L. and A. Woodford, 1999. Morpho-tectonics and mechanism of emplacement of the dolerite rings and sills of the Western Karoo, South Africa. South Afr. J. Geol., 102: 43-54.

Chevallier, L.P., M.L. Goedhart and A.C. Woodford, 2001. Influence of dolerite sill and ring complexes on the occurrence of groundwater in Karoo Fractured Aquifers: A morpho-tectonic approach. Water Research Commission, Pretoria, South Africa. https://www.bgs.ac.uk/africaGroundwaterAtlas/atla s.cfc?method=ViewDetails\&id=ZA1145

Cole, D.I., 1992. Evolution and Development of the Karoo Basin. In: Inversion Tectonics of the Cape Fold Belt, Karoo and Cretaceous Basins of Southern Africa, De Wit, M.J. and I.G.D. Ransome (Eds.). August Aime Balkema, Amsterdam, The Netherlands, pp: 87-100.

Cook, F.A., D.J. White, A.G. Jones, D.W.S. Eaton and J. Hall et al., 2010. How the crust meets the mantle: Lithoprobe perspectives on the Mohorovicic discontinuity and crust-mantle transition. Can. J. Earth Sci., 47: 315-351.

De Beer, J.H. and R. Meyer, 1983. Geoelectrical and gravitational characteristics of the Namaqua-Natal mobile belt and its boundaries. Spec. Publ. Geol. Soc. South Afr., 10: 91-100.

De Wit, M.J. and I.G.D. Ransome, 1992. Regional Inversion Tectonics Along the Southern Margin of Gondwana. In: Inversion Tectonics of the Cape Fold Belt, Karoo and Cretaceous Basins of Southern Africa, De Wit, M.J. and I.G.D. Ransome (Eds.). August Aime Balkema Publisher, Rotterdam, Netherlands, ISBN: 9789054100478, pp: 15-21.

De Wit, M.J., 2011. The great shale debate in the Karoo. South Afr. J. Sci., 107: 1-9.

Du Toit, A.L., 1920. The Karroo dolerites of South Africa: A study in hypabyssal injection. South Afr. J. Geol., 23: $1-42$.

Duba, A., S. Heikamp, W. Meurer, G. Mover and G. Will, 1994. Evidence from borehole samples for the role of accessory minerals in lower-crustal conductivity. Nat., 367: 59-61.

Enslin, S., 2015. Integrated geophysical investigation of the Karoo Basin, South Africa. Ph.D Thesis, University of the Witwatersrand, Johannesburg, South Africa.
Geel, C., M. de Wit, P. Booth, H.M. Schulz, B. Horsfield, 2015. Palaeo-environment, diagenesis and characteristics of Permian black shale's in the lower Karoo supergroup flanking the cape fold belt near Jansenville, Eastern Cape, South Africa: Implications for the shale gas potential of the Karoo Basin. South Afr. J. Geol., 118: 249-274.

Hartnady, C.J.H., P. Joubert and C.W. Stowe, 1985. Proterozoic crustal evolution in Southwestern Africa. Episodes, 8: 236-244.

Hunter, D.R. and D.L. Reid, 1987. Mafic Dyke Swarms in Southern Africa. In: Mafic Dyke Swarms, Halls, H.C. and W.F. Fahrig (Eds.). Geological Association of Canada, Newfoundland, Canada, pp: 445-456.

Johnson, M.R., 1991. Sandstone petrography, provenance and plate tectonic setting in Gondwana context of the South-Eastern Cape Karoo Basin. South Afr. J. Geol., 94: $137-154$.

Johnson, M.R., C.J. Van Vuuren, J.N.J. Visser, D.I. Cole and A.D.M. Christie et al., 2006. Sedimentary Rocks of the Karoo Supergroup. In: The Geology of South Africa, Johnson, M.R., C.R. Anhaeusser and R.J. Thomas (Eds.). Council for Geoscience, Pretoria South Africa, ISBN:9781919908779, pp: 461-499.

Johnson, M.R., C.J. van Vuuren, J. Visser, D. Cole and H. De Wickens et al., 1997. The Foreland Karoo Basin, South Africa. In: African Sedimentary Basins of the World, Selley, R. (Ed.). Elsevier, Amsterdam, Netherlands, pp: 269-317.

Johnson, M.R., C.J.V. Vuuren, W.F. Hegenberger, R. Key and U. Show, 1996. Stratigraphy of the Karoo Supergroup in Southern Africa: An overview. J. Afr. Earth Sci., 23: 3-15.

Kingsley, C.S., 1981. A composite submarine fan-delta-fluvial model for the Ecca and lower Beaufort Groups of Permian age in the Eastern Cape Province, South Africa. South Afr. J. Geol., 84: 27-40.

Kunetz, G., 1966. Principles of Direct Current-Resistivity Prospecting. Gebr Borntraeger, Stuttgart, Germany, Pages: 103.

Lindeque, A., M.J. De Wit, T. Ryberg, M. Weber and L. Chevallier, 2011. Deep crustal profile across the southern Karoo Basin and Beattie Magnetic Anomaly, South Africa: An integrated interpretation with tectonic implications. South Afr. J. Geol., 114: 265-292.

Linol, B., M.J. de Wit, E. Barton, F. Guillocheau and M.C. de Wit et al., 2015. Paleogeography and Tectono-Stratigraphy of Carboniferous-Permian and Triassic Karoo-Like Sequences of the Congo Basin. In: Geology and Resource Potential of the Congo Basin, De Wit, M.J., F. Guillocheau and M.C.J. de Wit (Eds.). Springer, Berlin, Germany, ISBN:978-3-642-29481-5, pp: 111-134. 
Milani, E.J. and M.J. de Wit, 2008. Correlations between the Classic Parana and Cape-Karoo Sequences of South America and Southern Africa and their Basin Infills Flanking the Gondwanides: Du Toit Revisited. In: West Gondwana: Pre-Cenozoic Correlations Across the South Atlantic Region, Pankurst, R.J., R.A.J. Trouw, B.B. De Brito Neves and M.J. De Wit (Eds.). Geological Society Special Publications, London, UK., ISBN:9781862392472, pp: 319-342.

Mjelde, R., A. Goncharov and R.D. Muller, 2013. The Moho: Boundary above upper mantle peridotites or lower crustal eclogites? A global review and new interpretations for passive margins. Tectonophysics, 609: 636-650.

Pangaro, F. and V.A. Ramos, 2012. Paleozoic crustal blocks of onshore and offshore central Argentina: New pieces of the Southwestern Gondwana collage and their role in the accretion of Patagonia and the evolution of Mesozoic South Atlantic sedimentary basins. Mar. Pet. Geol., 37: 162-183.

Pitts, B., M.J. Maher, J.H. De Beer, D.I. Gough and M.J. De Wit et al., 1992. Interpretation of Magnetic, Gravity and Magnetotelluric Data Across the Cape Fold Belt and Karoo Basin. In: Inversion Tectonics of the Cape Fold Belt, Karoo and Cretaceous Basins of Southern Africa, De Wit, M.J. and I.G.D. Ransome (Eds.). A.A. Balkema, Amsterdam, Netherlands, pp: 27-32.

Pous, J., G. Munoz, W. Heise, J.C. Melgarejo and C. Quesada, 2004. Electromagnetic imaging of Variscan crustal structures in Southwest Iberia: The role of interconnected graphite. Earth Planet. Sci. Lett., 217 : 435-450.

Rowsell, D.M. and A.M.J. De Swart, 1976. Diagenesis in Cape and Karroo sediments, South Africa and its bearing on their hydrocarbon potential. South Afr. J. Geol., 79: 81-145.

Smith, R.M.H., 1995. Changing fluvial environments across the Permian-Triassic boundary in the Karoo Basin, South Africa and possible causes of tetrapod extinctions. Palaeogeogr. Palaeoclimatol. Palaeoecol., 117: 81-104.

Smith, R.M.H., P.G. Eriksson and W.J. Botha, 1993. A review of the stratigraphy and sedimentary environments of the Karoo-aged basins of Southern Africa. J. Afr. Earth Sci., 16: 143-169.

Stankiewicz, J. and M. de Wit, 2013. The 3.5 billion years of reshaped Moho, Southern Africa. Tectonophysics, 609: 675-689.

Svensen, H., S. Planke, L. Chevallier, A. Malthe-Sorenssen and F. Corfu et al., 2007. Hydrothermal venting of greenhouse gases triggering Early Jurassic global warming. Earth Planet. Sci. Lett., 256: 554-566.
Talwani, M. and J.R. Hiertzler, 1964. Computation of magnetic anomalies caused by two dimensional bodes of arbitrary shape. Geol. Sci., 9: 464-480.

Talwani, M., J.L. Worzel and M. Landisman, 1959. Rapid gravity computations for two-dimensional bodies with application to the Mendocino submarine fracture zone. J. Geophys. Res., 64: 49-59.

Tankard, A., H. Welsink, P. Aukes, R. Newton and E. Stettler, 2009. Tectonic evolution of the Cape and Karoo basins of South Africa. Mar. Pet. Geol., 26: 1379-1412.

Tankard, A., H. Welsink, P. Aukes, R. Newton and E. Stettler, 2012. Geodynamic Interpretation of the Cape and Karoo Basins, South Africa. In: Regional Geology and Tectonics: Phanerozoic Passive Margins, Cratonic Basins and Global Tectonic Maps, Roberts, D.G. and A.W. Bally (Eds.). Elsevier, Amsterdam, Netherlands, ISBN:978-0-444-56357-6, pp: 868-945.

Tedla, G.E., M. Van Der Meijde, A.A. Nyblade and F.D. van der Meer, 2011. A crustal thickness map of Africa derived from a global gravity field model using Euler deconvolution. Geophys. J. Intl., 187: 1-9.

Telford, W.M., W.M. Telford, L.P. Geldart, R.E. Sheriff and R.E. Sheriff, 1990. Applied Geophysics. 2nd Edn./Vol. 1, Cambridge University Press, New York, USA., ISBN:9780521339384, Pages: 770.

Thybo, H. and I.M. Artemieva, 2013. Moho and magmatic underplating in continental lithosphere. Tectonophysics, 609: 605-619.

Turner, B.R., 1999. Tectonostratigraphical development of the Upper Karooforeland basin: Orogenic unloading versus thermally-induced Gondwana rifting. J. Afr. Earth Sci., 28: 215-238.

Van Zijl, J.S.V., 2006. A review of the resistivity structure of the Karoo Supergroup, South Africa with emphasis on the dolerites: A study in anisotropy. South Afr. J. Geol., 109: 315-328.

Van Zijl, J.S.V., 2006. Physical characteristics of the Karoo sediments and mode of emplacement of the dolerites. South Afr. J. Geol., 109: 329-334.

Van der Voort, I., 2001. Risk based decision tool for managing and protecting groundwater resources. Ph.D Thesis, University of the Free State, Bloemfontein, South Africa.

Weckmann, U., A. Jung, T. Branch and O. Ritter, 2007. Comparison of electrical conductivity structures and 2D magnetic modelling along two profiles crossing the Beattie Magnetic Anomaly, South Africa. South Afr. J. Geol., 110: 449-464. 
Weckmann, U., O. Ritter, A. Jung, T. Branch and M. De Wit, 2007. Magnetotelluric measurements across the Beattie magnetic anomaly and the Southern Cape conductive belt, South Africa. J. Geophys. Res. Solid Earth, 112: 1-10.

White, R.S., 1997. Mantle plume origin for the Karoo and Ventersdorp flood basalts, South Africa. South Afr. J. Geol., 100: 271-282.
Won, I.J. and M. Bevis, 1987. Computing the gravitational and magnetic anomalies due to a polygon: Algorithms and Fortran subroutines. Geophysics, 52: 232-238.

Woodford, A.C. and L.P. Chevallier, 2002. Regional Characterization and Mapping of Karoo Fractured Aquifer Systems: An Integrated Approach using a Geographical Information System and Digital Image Processing. Water Research Commission, Pretoria, South Africa, ISBN:9781868458660, Pages: 192. 